NBER WORKING PAPER SERIES

\title{
ENVIRONMENTAL CONTROLS, SCARCITY RENTS, AND PRE-EXISTING \\ DISTORTIONS
}

Don Fullerton

Gilbert Metcalf

Working Paper 6091
NATIONAL BUREAU OF ECONOMIC RESEARCH 1050 Massachusetts Avenue
Cambridge, MA 02138
July 1997

The authors gratefully acknowledge the comments of Richard Arnott, Larry Goulder, Dan Hamermesh, Michael Hanemann, Ian Parry, Jon Skinner, Kerry Smith, and Pete Wilcoxen. This research was partially supported by grants to the first author from the Environmental Protection Agency (EPA R824740-01-0) and to the second author from the National Science Foundation (NSF SBR-9514989) to the National Bureau of Economic Research. This paper is part of NBER's research program in Public Economics. Any opinions expressed are those of the authors and not those of the EPA, the NSF or the National Bureau of Economic Research.

(C) 1997 by Don Fullerton and Gilbert Metcalf. All rights reserved. Short sections of text, not to exceed two paragraphs, may be quoted without explicit permission provided that full credit, including $(\mathcal{O}$ notice, is given to the source. 
Environmental Controls, Scarcity Rents, and Pre-Existing Distortions

Don Fullerton and Gilbert Metcalf

NBER Working Paper No. 6091

July 1997

JEL Nos. H2, Q2

Public Economics

\begin{abstract}
Debate about the Double Dividend Hypothesis has focused on whether an environmental policy raises revenue that can be used to cut other distorting taxes. In this paper, we show that this focus is misplaced. We derive welfare results for alternative policies in a series of analytical general equilibrium models with clean and dirty goods that might be produced using emissions as well as other resources, in the presence of other pre-existing distortions such as labor taxes or even monopoly pricing. We show that the same welfare effects of environmental protection can be achieved, without exacerbating the labor distortion, by taxes that raise revenue, certain command and control regulations that raise no revenue, and even subsidies that cost revenue. Instead, the preexisting labor tax distortion is exacerbated by policies that generate privately-retained scarcity rents. These rents raise the cost of production, raise equilibrium output prices, and thus reduce the real net wage. Such policies include both quantity-restricting command and control policies and certain marketable permit policies.
\end{abstract}

Don Fullerton

Department of Economics

University of Texas at Austin

Austin, TX 78712

and NBER

dfullert@eco.utexas.edu
Gilbert Metcalf

Department of Economics

Tufts University

Medford, MA 02155

and NBER

gmetcalf@tufts.edu 
Considerable attention has centered recently on the hypothesis that taxes on polluting activities might yield a "double dividend" by helping not only to protect the environment but also to raise revenue that can be used to reduce other distorting taxes. This second dividend only arises, however, if the pollution tax is less distorting than the existing tax it replaces. As shown in Bovenberg and de Mooij (1994), the pollution tax itself raises product prices and thus reduces the real net wage. It can thus reduce labor supply and welfare by just as much as a tax on labor that it replaces. Indeed, if pre-existing taxes are already set optimally in terms of tax distortions, then the pollution tax could only do as well and might do worse than the pre-existing tax system (aside from the environmental benefits). In practice, actual tax rates are not set optimally, so the debate has focused on circumstances in which the pollution tax might be less distorting than some existing tax. This voluminous literature is reviewed in Goulder (1995) and Oates (1995).

What may seem obvious in this debate is that the pollution tax must raise welfare more than some other command and control (CAC) policy with the same environmental protection, because only the tax generates revenue to reduce other distorting taxes. If a pollution tax and a CAC pollution restriction have similar effects on product prices and thus on the real net wage, then they both exacerbate labor tax distortions. Only a revenue-raising instrument offers the chance to reduce the labor tax rate and thus to offset that negative effect on welfare.'

Indeed, the entire focus of the Double Dividend Hypothesis is on the welfare-raising potential of the revenue from the pollution $\operatorname{tax}^{2}$ In this paper we show that this focus is misplaced. In particular, we show that revenue-raising and non-revenue-raising policies can achieve equivalent welfare-raising effects of environmental protection without exacerbating the pre-existing distortions. These favorable effects can be achieved by taxes that raise revenue, certain $\mathrm{CAC}$ regulations that raise no revenue, and even subsidies that cost revenue. Instead, the exacerbation of the pre-existing tax distortion is associated with policies that generate privately-retained scarcity rents. It is those rents that raise costs of production, raise equilibrium output prices, and thus reduce the real wage. Such policies

${ }^{1}$ Papers that compare such environmental taxes to CAC regulation include Terkla (1984), Parry (1997a), and Goulder, Parry, and Burtraw (1996).

${ }^{2}$ The title of Terkla's (1984) paper is "The Efficiency Value of Effluent Tax Revenues." Other papers that discuss the revenue value of pollution taxes include Lee and Misiolek (1986), Pearce (1991), Repetto et al (1992), and Ballard and Medema (1993). 
include both quantity-restricting command and control policies and marketable permit policies in which the permits are given to existing polluters.

In a single general equilibrium framework, we solve analytically for expressions that show all relevant effects of a number of policies on the equilibrium quantity of emissions, the quantity and price of each output, the generation of profits, price and income effects on labor supply, improvement in the environment, and the net effect on welfare. We use the same model to provide comparable analyses of at least five kinds of environmental policies, including: a pollution tax, an environmental subsidy, tradeable permits, a CAC policy that restrict emissions, and a different $\mathrm{CAC}$ policy that restricts technology. We analyze the same set of policies for alternative versions of the model, including one version with fixed emissions per unit of output, another with variable emissions per unit of output, and a third version with a pre-existing monopoly distortion in the market for the polluting good. ${ }^{3}$

We proceed in the first section below to overview our model and results. Section II then specifies the general equilibrium model, while subsequent sections present results for (III) the fixed-emissions case, (IV) the variable-emissions case, (V) an environmental subsidy, (VI) technology restrictions, and (VII) the monopoly model.

\section{An Overview}

We start with many identical consumers that maximize utility defined over a clean good, a dirty good, leisure, environmental quality, and a government-provided public good. ${ }^{4}$ With linear production using only one resource, the model and results of Bovenberg and de Mooij (1994) represent a special case of ours. Starting with an uncorrected externality and a pre-existing labor tax, we introduce a small permit or CAC policy that begins to restrict the quantity of pollution, and we solve for equilibrium prices, profits, labor supply, and welfare. As in Parry (1997a), but using a more explicit utility-maximization framework for

${ }^{3}$ Multiple distortions have been analyzed in partial equilibrium models (e.g. Barnett, 1980, or Browning, 1994), or computable general equilibrium models (e.g. Harris, 1984), but our model below is the only one we are aware of that finds analytical solutions for a general equilibrium with all three distortions simultaneously: a tax that distorts labor supply decisions, a monopoly that distorts output decisions, and an environmental externality that distorts input decisions.

${ }^{4}$ If government cannot observe individual differences, then it cannot use individualspecific lump sum taxes. We abstract from heterogeneity, but still assume that the government cannot use lump sum taxes. For an interpretation of environmental taxes that incorporates heterogeneity, see Kaplow (1996). 
welfare results, we insert plausible parameter values to show that the gain from environmental improvement can be more than offset by the loss from exacerbating the labor supply distortion. ${ }^{5}$

We then extend the model to consider variable emissions per unit of output. One might write a production function for the dirty good where both the output and the waste by-product are produced using inputs like labor, capital, and other resources. Using a device common in environmental economics, however, we simply move the waste emissions to the other side of the equation. In other words, we view emissions as an input to production, with its own downward sloping marginal product curve (since successive units of emissions are less crucial to production). In addition, we modify that production function by lumping together labor, capital and other resources. Distinction among these inputs is not necessary for any of the points we make below. Therefore, in our model, one "clean" good is produced using just this single resource, and one "dirty" output is produced using only two inputs: one input is same kind of resource (labor or capital) used elsewhere in the economy, and the other input is "emissions." The elasticity of substitution between these two inputs will help determine pollution abatement possibilities. Finally, we specify that these wastes themselves are associated with some use of resources (labor or capital) necessary to transport and dispose of them.

Using this variable-emissions model, we derive new expressions for general equilibrium outcomes and again calculate welfare effects. We also show the sensitivity of results to alternative parameter values. We use this model to analyze a tax on emissions (generalizing Bovenberg and de Mooij, 1994), a permit or other restriction on emissions (as in Parry, 1997a), or an environmental subsidy (as in Ballard and Medema, 1993, or Parry, 1997b). We confirm prior results that the tax on emissions does not exacerbate the labor supply distortion, if the revenues are used to reduce the pre-existing labor tax rate, because the effect of higher product prices on the real net wage is effectively offset by the reduction in the labor tax.

This emissions tax is equivalent to a policy in which permits are sold by government,

${ }^{5}$ As described below, we use a labor tax rate of $40 \%$, an uncompensated labor supply elasticity of 0.1 or 0.3 , an income elasticity of labor supply equal to -0.2 , and thus a compensated elasticity of 0.3 or 0.5 . The welfare cost "triangle" from this labor tax is substantial, and any policy that raises product prices and reduces the real net wage effectively adds to the wide side of this triangle. 
if we still assume that the revenue is used to reduce the labor tax rate. In actual permit schemes like the sulfur dioxide provisions of the Clean Air Act Amendments of 1990, however, most of the permits are handed out for free to existing firms in a way that allows permit recipients to keep the scarcity rents. If a profits tax does not usurp all of those rents, then we show that government does not have enough revenue to reduce the labor tax enough to offset the effect of higher prices on the real net wage. ${ }^{6}$

Several papers have focused on the revenue-raising potential of various policies. For example, Parry (1997a) shows that a non-revenue-raising policy to restrict dirty activities (by a quota or limited number of permits) still raises output price and exacerbates labor tax distortions. This negative effect on welfare can exceed the positive effect from environmental improvements. Goulder, Parry, and Burtraw (1996) provide both an analytical model and a computable general equilibrium (CGE) model of the U.S. economy in which they compare revenue-raising instruments (emissions taxes) and non-revenueraising instruments (permits that are given away) to abate sulfur dioxide emissions. ${ }^{7}$ They find that the revenue-raising policy always yields higher welfare than the non-revenue-raising policy, and again find that the latter can actually reduce welfare. They thus conclude that raising revenue is crucial to understanding the welfare impact of environmental controls.

For these two policies, welfare certainly is higher for the one that raises revenue. Indeed, the entire double-dividend literature focuses on the revenue from pollution taxes. In this paper, however, we depart from the Double Dividend literature in several important ways. First, we provide results for more types of policies such as a subsidy to the clean good, or a restriction on the technology of producing the dirty good. This contribution is important, because it clarifies that the key distinction is not between revenue-raising and non-revenue-raising policies. A subsidy to the clean good is a revenue-loser, and must be financed by raising the labor tax rate, but we show that it has the same favorable net welfare effects as the tax on the dirty good -- a tax that generates revenue used to cut the labor tax rate. The reason is that the subsidy reduces product prices in a way that raises the real net

${ }^{6}$ Analogously, Bovenberg and Goulder (1996) show that if the environmental tax revenue is returned to consumers in a lump sum fashion, instead of reducing the labor tax rate, then labor supply falls and net welfare may fall.

${ }^{7}$ They decompose the welfare impact of these policies into 1) a revenue recycling effect, 2) a tax interaction effect, and 3) an environmental effect. This breakdown provides a useful basis for interpreting their simulation results. 
wage enough to offset the required increase in the labor tax rate. Moreover, we evaluate a different kind of CAC policy that restricts technologies instead of emissions. This CAC policy raises no revenue, but it still achieves the same favorable welfare effects as the tax or subsidy policies. The key difference is that this CAC policy does not create rents. We conclude that the appropriate emphasis in environmental policy design is not on revenue raising, but on avoiding conditions that generate privately-retained profits which in turn increase costs and reduce the real net wage. ${ }^{8}$

Second, for this reason, we focus our attention on the nature of the mechanism that creates scarcity rents, and on the disposition of those rents. We allow government to use another policy parameter, a tax rate on profits, and we show how welfare depends critically on this parameter. Only if government gets $100 \%$ of the rents can the labor tax be reduced enough to eliminate adverse effects on the labor supply distortion. As a consequence, a "revenue-raising" policy of selling some portion of the permits or taxing some portion of the rents provides unambiguously lower welfare in our model than the non-revenue-raising CAC technology restriction that avoids the creation of the rents in the first place.

Third, we extend results to the case with a pre-existing monopoly distortion as well as the pre-existing labor supply distortion. Environmental policy might then exacerbate both distortions, by raising further the price of the monopolized output and reducing further the real net wage rate.

\section{The Model}

Our goal is to analyze and compare the impacts of five different kinds of policies such as tradeable pollution permits, a command and control (CAC) limit on emissions, a tax on emissions, a subsidy to clean production, or a CAC restriction on technology. In particular, we wish to compare all such policies within a single model. For this purpose, we develop a simple model with $\mathrm{N}$ identical individuals who own a single resource and sell it in the market to earn income that can be used to buy two different goods. ${ }^{9}$

\footnotetext{
${ }^{8} \mathrm{We}$ focus on a subsidy to the clean good that reduces its product price (and thus increases the real net wage). A different kind of subsidy to abatement in the dirty industry might raise the opportunity cost of emissions (the subsidy foregone). This latter kind of subsidy might raise the price of output and thus generate privately-retained scarcity rents.

${ }^{9}$ Our framework is similar to that of Bovenberg and de Mooij (1994), but they employ only linear production with a fixed amount of pollution per unit output, and they analyze only a tax on the dirty good. We consider more general production with variable pollution per unit output, and we analyze all five kinds of policies just listed in the text.
} 


\section{A. The Basic Set-up}

This static model considers only one time period, with no saving decision. For simplicity we refer to the resource as time available for labor supply, but under some conditions it can be interpreted more generally as a fixed total amount of labor, capital, land, and any other resource that can be sold in the market (in amount L) or used at home (in amount $\mathrm{L}_{\mathrm{H}}$ ). The resource kept at home could be interpreted either as leisure or as a resource used in home production. We assume perfect certainty, no transactions costs, and constant returns to scale production. ${ }^{10}$

Each individual receives utility from per-capita amounts of a nonpolluting good (X), a polluting good $(\mathrm{Y})$, and leisure $\left(\mathrm{L}_{\mathrm{H}}\right)$, and from the total amounts of a governmentprovided nonrival public good (G), and another nonrival public good called environmental quality $(E)$. The per-capita amount $\mathrm{Y}$ is produced using per-capita amounts of labor $\left(\mathrm{L}_{\mathrm{Y}}\right)$ and of emissions (Z). Total emissions (NZ) negatively affect the environment through:

$$
\mathrm{E}=\mathrm{e}(\mathrm{NZ}), \quad \text { where } \mathrm{e}^{\prime}<0 \text {. }
$$

The other goods are produced according to:

$$
\begin{gathered}
X=L_{X} \\
Y=F\left(L_{Y}, Z\right) \\
G=N_{G}
\end{gathered}
$$

We define a unit of $\mathrm{X}$ as the amount that can be produced using one unit of labor. The numeraire good is $\mathrm{L}$, or equivalently $\mathrm{X}$. Then $\mathrm{Y}$ is produced in a constant returns to scale function $(F)$, using clean labor $\left(\mathrm{L}_{\boldsymbol{\gamma}}\right)$ and emissions $(\mathrm{Z})$. These emissions may include

${ }^{10}$ These considerations might also affect the choice among policy instruments. Other models have analyzed uncertainty (Weitzman, 1974), monitoring and enforcement costs (Russell, 1990), and transactions costs (Stavins, 1995). The large literature on the choice among policy instruments is reviewed in Bohm and Russell (1985). Constant returns to scale means that all firms are identical in our model, but if abatement costs differ significantly among firms with different technologies, and if regulators have imperfect information about these differences, then imperfect CAC policies can be six to ten times as expensive as the minimum abatement cost made possible by incentive-based policies like taxes or permits (see Atkinson and Lewis, 1974, Seskin, Anderson and Reid, 1983, and other studies surveyed in Cropper and Oates, 1992, p. 686). 
gaseous, liquid, or solid wastes that require some private costs for removal and disposal. These private costs must come in the form of resources, so we define one unit of emissions as the amount that requires one unit of private resources $\left(\mathrm{Z}=\mathrm{L}_{\mathrm{Z}}\right) \cdot{ }^{11}$ Thus, the private cost of $\mathrm{Z}$ is always 1 . We define a unit of $\mathrm{Y}$ such that its initial competitive equilibrium price is $\mathrm{p}_{\mathrm{Y}}=1$. Finally, some labor $\left(\mathrm{L}_{\mathrm{G}}\right)$ is also used to produce the public good. The combination of these production relationships provides the overall resource constraint:

$$
\mathrm{NL}=\mathrm{NX}+\mathrm{N}\left(\mathrm{L}_{\mathrm{Y}}+\mathrm{L}_{\mathrm{Z}}\right)+\mathrm{G}
$$

Individuals maximize:

$$
\mathscr{L}=U\left(X, Y, L_{H}, G, E\right)+\lambda\left[\left(1-t_{L}\right) L+M-X-p_{Y} Y\right]
$$

by their choice of $X, Y$, and $L_{H}$, where $t_{L}$ is the tax rate on resource (labor) supply, and $M$ is nonlabor income discussed below. Taxable labor supply is $L=L_{X}+L_{Y}+L_{Z}+L_{G}$. A subscript on $U$ indicates a partial derivative (marginal utility), and $U_{H}$ is the partial of $U$ with respect to $L_{H}$, so these individuals set $U_{X}=U_{Y} / p_{Y}=U_{H} /\left(1-t_{L}\right)=\lambda$, the marginal utility of income.

Our approach is to start at an initial competitive equilibrium with an existing tax on labor, but without any policy correction for the external effect of $Z$ on $E$, and then to analyze small changes. The effect of any such change on utility can be found by total differentiating $\mathrm{U}$ :

$$
d U=U_{X} d X+U_{Y} d Y-U_{H} d L+U_{E} e^{\prime} N d Z
$$

where $\mathrm{G}$ is held fixed by assumption. ${ }^{12}$ Thus, to balance the government's budget, any

${ }^{11}$ Note that emissions are positively related to the use of these resources: $\mathrm{L}_{\mathrm{Z}}$ is not to clean up or reduce emissions, but just to cart it away. Abatement is undertaken by substituting away from $\mathrm{Z}$ and into $\mathrm{L}_{\mathbf{Y}}$. This overall production function is still constant returns to scale, since $\mathrm{Z}$ is a linear function of $\mathrm{L}_{\mathrm{Z}}$. The private cost for emissions helps justify our assumption of an internal solution with a finite choice for $Z$, even without corrective government policy.

${ }^{12}$ This $G$ is required in the model to justify the collection of taxes (see eq. 11). 
environmental policy that reduces labor supply must also specify how the lost labor tax revenue will be recovered. Substituting the consumer's first order conditions into (5) yields:

$$
d U=\lambda d X+\lambda p_{Y} d Y-\lambda\left(1-t_{L}\right) d L+U_{E} e^{\prime} N d Z
$$

Totally differentiate the resource constraint (3), with $d G=0$, to get $d X=d L-d L_{Y}-d L_{Z}$, and:

$$
d U / \lambda=t_{L} d L-\mu d Z+\left(p_{Y} d Y-d L_{Y}-d L_{Z}\right)
$$

where $\mathrm{dL}_{\mathrm{Z}}=\mathrm{dZ}$, and where $\mu$ is defined as $-\mathrm{NU}_{\mathrm{E}} \mathrm{e}^{\prime} / \lambda$. This $\mu>0$ is the dollar value of lost utility to all individuals from a marginal increase in emissions, that is, "marginal environmental damage".

Next, totally differentiate the production function for $\mathrm{Y}$ :

$$
d Y=F_{Y} d L_{Y}+F_{Z} d Z
$$

where $F_{Y}$ and $F_{Z}$ are the marginal products of $L_{Y}$ and $Z$. Assuming profit maximization (and a zero initial tax on emissions), these marginal products are equal to factor prices divided by output price: $\mathrm{F}_{\mathrm{Y}}=\mathrm{F}_{\mathrm{Z}}=1 / \mathrm{p}_{\mathrm{Y}}=1$. Thus, from (8), the expression in parentheses in (7) is zero. We divide (7) by $\mathrm{L}$, and use a hat over a variable to indicate a rate of change $(\hat{\mathrm{L}}=\mathrm{dL} / \mathrm{L})$. Thus:

$$
\frac{\mathrm{dU}}{\lambda \mathrm{L}}=\mathrm{t}_{\mathrm{L}} \hat{\mathrm{L}}-\mu\left(\frac{\mathrm{Z}}{\mathrm{L}}\right) \hat{\mathrm{Z}}
$$

This equation represents our first main result. The left-hand side is the dollar value of the change in utility $(\mathrm{dU} / \lambda)$, divided by total income $(\mathrm{L})$. On the right-hand side are two terms. The policy under consideration is a mandated reduction in emissions, or some incentive that reduces emissions, so $\hat{\mathrm{Z}}<0$. Thus the second term on the right-hand side of (9) is an unambiguous increase in utility from abating pollution. The impact will depend on the importance of the externality (size of $\mu$ ), the percentage reduction in $\mathrm{Z}$, and the initial size of $\mathrm{Z}$ relative to the size of the economy. In the first term, however, utility is also affected by a pre-existing labor tax $\left(t_{L}>0\right)$. If the policy reduces labor supply, utility will fall by the exacerbation of a pre-existing labor supply distortion. The overall effect on welfare depends 
on the change in labor supply, and on the relative size of these two terms.

\section{B. Alternative Policies, Profits, and Revenues}

In order to derive an expression for the change in labor supply, $\hat{\mathrm{L}}$, we need to trace the effect of the policy on the price of emissions, the price of output, and thus on the real net wage. We also need to trace the effect of the policy on income flows that might also affect labor supply. These income effects include the possibility that the policy generates private profits.

Any policy to reduce $\mathrm{Z}$ will raise the marginal product of $\mathrm{Z}$ above its private cost. If the government imposes a tax on emissions, or sells a limited number of emission permits, then the firm faces a price $p_{z}$ that equals the private resource cost plus the tax or the price of the permit. For these two policies, the scarcity rent goes to the government.

If the limited number of permits are handed out for free, however, then the scarcity rent goes to the permit recipient. These permits can be used by the recipients, to yield a marginal product of emissions greater than the private cost of emissions, or they can be sold. Either way, the policy has generated a private profit. We define these profits as:

$$
\Pi=\left(\mathrm{p}_{\mathrm{Z}}-1\right) \mathrm{Z}
$$

The rules for the initial allocation of these permits does not matter in our model, because the single representative agent must own whatever firm or other entity is given the permits. These profits become part of nonlabor income, $M$ in equation (4).

These profits may arise for some kinds of command-and-control (CAC) policies as well. One example is a "new source performance standard" that requires an expensive technology for new firms only, raising the marginal cost of production (and thus the equilibrium price of output) without affecting the cost of production for old firms. The result is an entry barrier that provides profits to old firms. ${ }^{13}$ Our model does not distinguish new firms from old firms, but profits can arise in other ways. For the simplest example, consider the special case where production of $\mathrm{Y}$ uses fixed combinations of $L_{Y}$ and $\mathrm{Z}$. Then a restriction on $\mathrm{Z}$ is equivalent to a restriction on $\mathrm{Y}$. What happens if all firms are required to produce at $90 \%$ of last year's level? The result is a government-mandated cartel

\footnotetext{
${ }^{13}$ See Buchanan and Tullock (1975) or Maloney and McCormick (1982).
} 
that allows all firms to charge a price greater than marginal cost. ${ }^{14}$

We start at a competitive equilibrium with no environmental policy and zero profits, and we introduce a new policy such as $\hat{Z}<0$. Any generated profits might affect consumer behavior and government revenue. Thus, prior to any policy, $\mathrm{p}_{z}=1$ and $I I$ in equation (10) is zero. The change in profits $(d I I)$ equals $\left(Z_{d p}+p_{Z} d Z-d Z\right)$, which equals $Z d p_{Z}$ (since the initial $\mathrm{p}_{Z}$ is 1 ).

We now specify how the government responds to a loss in tax base. A general way to state the government budget constraint is:

$$
\mathrm{G}=\mathrm{Nt}_{\mathrm{L}} \mathrm{L}+\mathrm{Nt}_{\Pi} \Pi
$$

where $t_{\Pi}$ is a tax on profits. We can then set this tax rate (exogenously) to 1.0 for any case where government receives the scarcity rent, such as for an emissions tax or sale of permits, and we set it to zero for the other extreme where private parties keep the rents. This specification also allows us to consider the case where a pre-existing corporate profits tax rate would take part of the firm's private profits. We do not adjust this tax rate endogenously to help maintain the necessary revenue to pay for $G$, but its existence greatly affects the amount by which the labor tax might have to be adjusted. Suppose, for example, that a permit or CAC policy generates profits but also reduces labor supply and thus labor tax revenue. If the tax rate on profits is zero, then the government will have to raise the labor tax rate and exacerbate labor supply distortions. If $t_{\Pi I}$ equals 1 , then the government may be able to reduce the labor tax rate.

Differentiate the government budget (eq. 11 ), set $d G=0$, and use $\mathrm{dII}=\mathrm{Zdp}_{z}$ to get:

$$
\hat{\mathrm{t}}_{\mathrm{L}}=-\left(\frac{\mathrm{t}_{\mathrm{L}}}{1-\mathrm{t}_{\mathrm{L}}}\right) \hat{\mathrm{L}}-\mathrm{t}_{\Pi}\left(\phi \frac{\mathrm{Z}}{\mathrm{Y}}\right) \hat{\mathrm{p}}_{\mathrm{Z}}
$$

${ }^{14}$ These profits still arise with substitution between $\mathrm{L}_{Y}$ and $\mathrm{Z}$. In our model, with perfect competition and constant returns to scale, identical firms would have no reason to buy or sell permits from each other anyway, so the tradeable permit equilibrium (with scarcity rents) must be functionally equivalent to the CAC equilibrium (with each firm's emissions limited to $90 \%$ of last year's level). The point is that the firm does not have to sell the permit to receive a profit: a mandated restriction still raises the marginal product of $\mathrm{Z}$ above its cost. 
where $\hat{t}_{\mathrm{L}}=\frac{\mathrm{dt}_{\mathrm{L}}}{1-\mathrm{t}_{\mathrm{L}}}$ and $\phi=\frac{\mathrm{p}_{\mathrm{Y}} \mathrm{Y}}{\mathrm{X}+\mathrm{p}_{\mathrm{Y}} \mathrm{Y}}=\frac{\mathrm{p}_{\mathrm{Y}} \mathrm{Y}}{\left(1-\mathrm{t}_{\mathrm{L}}\right) \mathrm{L}}$. This is the rate at which government has to change the labor tax. To evaluate this expression, we need to solve for $\hat{\mathrm{L}}$ and $\hat{\mathrm{p}}_{\mathrm{Z}}$.

\section{Effects on Labor Supply}

To determine specific effects on labor supply, we follow Bovenberg and de Mooij (1994) by assuming that $G$ and $E$ are separable in utility from leisure and consumption, and that the combination of consumption goods is homothetic and separable from leisure:

$$
\mathrm{U}=\mathrm{U}\left(\mathrm{V}\left[\mathrm{Q}(\mathrm{X}, \mathrm{Y}), \mathrm{L}_{\mathrm{H}}\right], \mathrm{G}, \mathrm{E}\right)
$$

where $\mathrm{Q}$ is a homothetic function of $\mathrm{X}$ and $\mathrm{Y}$. The household budget is given by:

$$
X+p_{Y} Y=\left(1-t_{L}\right) L+\left(1-t_{\Pi}\right) \Pi
$$

Define $w$ as the real net wage, so $w=\left(1-l_{L}\right) / p_{Q}$ where $p_{Q}$ is a price index on $Q(X, Y)$. This index assigns a weight $\phi$ to $\mathrm{p}_{\mathrm{Y}}$, so $\hat{\mathrm{p}}_{\mathrm{Q}}=\phi \hat{\mathrm{p}}_{\mathrm{Y}}$. Totally differentiate $\mathrm{w}$ to get:

$$
\hat{w}=-\hat{t}_{L}-\phi \hat{p}_{Y}
$$

This equation says that the real net wage falls if either the tax on labor were to rise, or if the price of consumption goods were to rise. Next we find how $\mathrm{p}_{\mathrm{Y}}$ is related to the cost of $\mathrm{Z}$ by using the zero-profits condition to show that $\hat{\mathrm{p}}_{\mathrm{Y}}=(\mathrm{Z} / \mathrm{Y}) \hat{\mathrm{p}}_{\mathrm{Z}} \cdot{ }^{15}$ Then, using (12) in (15), we have:

$$
\hat{\mathrm{w}}=\left(\frac{\mathrm{t}_{\mathrm{L}}}{1-\mathrm{t}_{\mathrm{L}}}\right) \hat{\mathrm{L}}-\left(1-\mathrm{t}_{\Pi}\right) \phi\left(\frac{\mathrm{Z}}{\mathrm{Y}}\right) \hat{\mathrm{p}}_{\mathrm{Z}}
$$

Labor is chosen by maximizing the sub-utility function $\mathrm{V}\left(\mathrm{Q}, \mathrm{L}_{\mathrm{H}}\right)$ subject to:

$$
\mathrm{Q}=w \mathrm{~L}+\left(1-\mathrm{t}_{\Pi}\right) \Pi / \mathrm{p}_{\mathrm{Q}}
$$

${ }^{15}$ Profits are created by $p_{Z}>1$, but the firm breaks even on output given that higher cost of $\mathrm{Z}$. The zero-profits condition is $\mathrm{p}_{\mathrm{Y}} \mathrm{Y}=\mathrm{L}_{\mathrm{Y}}+\mathrm{p}_{\mathrm{Z}} \mathrm{Z}$. Totally differentiate, and use the fact shown above (at equation 8) that $d Y=d L_{Y}+d Z$, to get $d_{p_{Y}} Y=d p_{Z} Z$. Initial prices are one, so $\hat{\mathrm{p}}_{\mathrm{Y}}=(\mathrm{Z} / \mathrm{Y}) \hat{\mathrm{p}}_{\mathrm{Z}}$. 
We can write the labor supply function resulting from this maximization problem as $\mathrm{L}=$ $\mathrm{L}\left(\mathrm{w},\left(1-\mathrm{t}_{\Pi}\right) \Pi / \mathrm{p}_{\mathrm{Q}}\right)$. That is, labor supply depends on uncompensated effects of the real net wage, and it depends on additional income effects of real net profits. Totally differentiating this function yields:

$$
\hat{\mathrm{L}}=\epsilon \hat{\mathrm{w}}+\left(1-\mathrm{t}_{\Pi}\right) \eta \phi\left(\frac{\mathrm{Z}}{\mathrm{Y}}\right) \hat{\mathrm{p}}_{\mathrm{Z}}
$$

where $\epsilon$ is the uncompensated labor supply elasticity, and $\eta$ is the income elasticity of labor supply. Substituting equation (16) into (18) gives the labor supply response as a function of the increase in the price of $\mathrm{Z}$ :

$$
\hat{\mathrm{L}}=\frac{\left(1-\mathrm{t}_{\Pi}\right)\left(1-\mathrm{t}_{\mathrm{L}}\right)(\eta-\epsilon) \phi}{1-\mathrm{t}_{\mathrm{L}}-\epsilon \mathrm{t}_{\mathrm{L}}}\left(\frac{\mathrm{Z}}{\mathrm{Y}}\right) \hat{\mathrm{p}}_{\mathrm{Z}}
$$

The point of this equation is that environmental policy raises the cost of emissions, and thus the cost of output, in a way that reduces $w$ and affects labor supply. Notice that the tax on profits $t_{\Pi I}$ is very important for damping the impact of a price change on labor supply. In the limit when all profits are taxed away, labor supply does not respond at all!

We still need to show how $\mathrm{p}_{\mathrm{z}}$ depends on the policy $\hat{\mathrm{Z}}<0$. In particular, the increase in $\mathrm{p}_{\mathrm{Z}}$ depends on the demand for $\mathrm{Z}$, which depends on the demand for $\mathrm{Y}$.

\section{Effects on Output of the Polluting Good}

The demand for $\mathrm{Y}$ is based on the consumer's maximization of $\mathrm{Q}(\mathrm{X}, \mathrm{Y})$, where we define $\sigma_{\mathrm{Q}}$ as the elasticity of substitution. Given this definition, and given that the price of $\mathrm{X}$ always equals 1 , we have the basic behavioral relationship:

$$
\hat{Y}=\hat{X}-\sigma_{Q} \hat{p}_{Y}
$$

We need to eliminate $\hat{\mathrm{X}}$ from the expression. Totally differentiate the household budget constraint (14), without holding any variables constant, and rearrange to solve for $\hat{\mathrm{X}}$. Substitute that expression into (20), and rearrange to get:

$$
\hat{\mathrm{Y}}=\hat{\mathrm{L}}+\hat{\mathrm{w}}+\phi\left(1-\mathrm{t}_{\Pi}\right) \hat{\mathrm{p}}_{\mathrm{Y}}-\sigma_{\mathrm{Q}}(1-\phi) \hat{\mathrm{p}}_{\mathrm{Y}}
$$

The first two terms give the income effect on $\mathrm{Y}$ from the change in labor income, which 
implicitly incorporates the government's adjustment of $t_{L}$. The third term represents the income effect of profits on the demand for $\mathrm{Y}$. The last term is the substitution effect.

Next, substitute equations (16) and (19) into (21) to obtain $\hat{Y}$ as a function of $\hat{p}_{Y}$ :

$$
\hat{\mathrm{Y}}=\left\{\frac{\left(1-\mathrm{t}_{\Pi}\right) \phi(\eta-\epsilon)-\sigma_{\mathrm{Q}}(1-\phi)\left(1-\mathrm{t}_{\mathrm{L}}-\epsilon \mathrm{t}_{\mathrm{L}}\right)}{1-\mathrm{t}_{\mathrm{L}}-\epsilon \mathrm{t}_{\mathrm{L}}}\right\} \hat{\mathrm{p}}_{\mathrm{Y}} \equiv \gamma_{\mathrm{Y}} \hat{\mathrm{p}}_{\mathrm{Y}}
$$

The expression $\gamma_{\mathrm{Y}}$ represents the full general equilibrium response of $\mathrm{Y}$ to a change in its price, incorporating household behavior as well as the government budget constraint.

Finally, we combine equations (19) and (22) to obtain:

$$
\hat{\mathrm{L}}=\left(1-\mathrm{t}_{\Pi}\right)\left\{\frac{\left(1-\mathrm{t}_{\mathrm{L}}\right) \phi(\eta-\epsilon)}{\left(1-\mathrm{t}_{\Pi}\right) \phi(\eta-\epsilon)-\sigma_{\mathrm{Q}}(1-\phi)\left(1-\mathrm{t}_{\mathrm{L}}-\epsilon_{\mathrm{L}}\right)}\right\} \hat{\mathrm{Y}} \equiv\left(1-\mathrm{t}_{\Pi}\right) \Delta \hat{\mathrm{Y}}
$$

To guarantee that $\Delta>0$, we assume that leisure is a normal good $(\eta<0)$, and that the labor supply curve is not backward-bending $(\epsilon>0)$. Thus the numerator is negative, and the denominator is negative as long as $\epsilon<\left(1-\mathrm{t}_{\mathrm{L}}\right) / \mathrm{t}_{\mathrm{L}}{ }^{16}$ In a later section we show how the mandated reduction in emissions $(\hat{Z}<0)$ also reduces $Y$. In the simplest case with fixed coefficients, $\hat{\mathrm{Y}}=\hat{\mathrm{Z}}$. Equation (23) then says the following: if government acquires all the rents for use in reducing labor tax rates (that is, if $t_{\Pi}=1$ ), then the policy will not affect labor supply and will not exacerbate labor tax distortions. Otherwise, labor supply will fall.

\section{Results With Fixed Pollution Per Unit Output}

Before continuing the derivations for the general case with variable emissions, we can pause to provide some numerical results for a special case with fixed emissions. In fact, suppose the good itself generates externalities either in production or in consumption, that is, where $\mathrm{Y}=\mathrm{Z} .{ }^{17}$ Then $\hat{\mathrm{Y}}=\hat{\mathrm{Z}}$, and $\hat{\mathrm{p}}_{\mathrm{Y}}=\hat{\mathrm{p}}_{\mathrm{Z}}$. In above formulas, we assume $\mathrm{Z} / \mathrm{Y}$ equals 1 , and $\mathrm{L}_{\mathrm{Y}}$ equals 0 . Then substitute eq. (23) into (9) to obtain the welfare impact:

\footnotetext{
${ }^{16}$ This condition will be satisfied if the initial point is on the normal side of the Laffer curve. Define revenue as $\mathrm{R}=\mathrm{Lt}_{\mathrm{L}}$, totally differentiate, and rearrange to get $\hat{\mathrm{R}} \hat{\mathrm{t}}_{\mathrm{L}}=\left(1-\mathrm{t}_{\mathrm{L}}\right) / \mathrm{t}_{\mathrm{L}}-\epsilon$.

${ }^{17}$ Examples include gasoline, and cigarettes, where the environmental problem is not from one of the inputs to production, but from the use of the final product. For these two examples, it is easy to see how a mandated reduction of every firm's output could generate private profits!
} 


$$
\frac{\mathrm{dU}}{\lambda \mathrm{L}}=\left\{\mathrm{t}_{\mathrm{L}}\left(1-\mathrm{t}_{\Pi}\right) \Delta-\mu\left(\frac{\mathrm{Y}}{\mathrm{L}}\right)\right\} \hat{\mathrm{Y}} \equiv-\psi \hat{\mathrm{Y}}
$$

Utility increases only if the cost of the larger labor supply distortion $\left(t_{L}\left(1-t_{\Pi}\right) \Delta\right)$ is less than the benefits from reducing pollution $(\mu \mathrm{Y} / \mathrm{L})$. Since $\hat{\mathrm{Y}}$ is negative, the sign of $\psi$ indicates the net effect on welfare.

Consider plausible magnitudes for the various parameters in (24). For $t_{L}$, we want a tax rate that applies to income from all household resources (that is, national income). Total government spending in the U.S. is roughly $35 \%$ of national income, but incentives depend on a marginal tax rate that exceeds this average tax rate. We feel that $t_{L}=0.5$ would be a reasonable choice to account for the progressive federal income tax, plus payroll tax, plus state and local income taxes, plus sales and excise taxes. All of these taxes apply to market goods and not to leisure. However, since the rate in our model is both an average rate and a marginal rate, we settle on $t_{L}=0.4 .^{18}$

For the uncompensated labor supply elasticity $\epsilon$, we need a single value to represent an aggregate of all potential workers and all labor supply effects from changes in wages. As discussed in Rosen (1980), these effects include not only hours worked, but also participation decisions and effort on the job. Thus, the typical hours elasticity likely understates the overall impact of changes in the real net wage. The literature includes many estimates of the hours elasticity that are small or negative for men, and other estimates that are large and positive for women. ${ }^{19}$ These estimates do not include participation decisions. Few have attempted to aggregate and summarize all such effects into one number. One such attempt is in Russek (1996). Taking into account both hours and participation, using many existing estimates for both men and women, he concludes that "the total wage elasticity for the labor supply of the economy seems to range somewhere between zero and $0.3^{\prime \prime}(\mathrm{p} .10) .^{20}$ In this study, we employ both 0.1 and 0.3 as reasonable alternatives for the overall uncompensated wage elasticity $(\epsilon)$.

${ }^{18}$ An overall labor tax rate of 0.4 has become a standard assumption in the literature on marginal excess burden, including Stuart (1984) and Browning (1987).

${ }^{19}$ In a questionnaire sent to labor economists, Fuchs, Krueger, and Poterba (1997) find that the mean belief is that the hours elasticity is zero for men and 0.45 for women.

${ }^{20}$ Feldstein (1995) points out other behavioral alternatives to taxable labor supply, and he finds that the relevant elasticity is at least 1.0 and could be higher. 
Russek (1996) also finds that the aggregate income elasticity is about -0.30 for women and about -0.10 for men. We use -0.2 for the aggregate income elasticity $(\eta)$, so the compensated labor supply elasticity $(\epsilon-\eta)$ is either 0.3 or 0.5 . Note, by the way, that CAC or permit polices will still affect welfare, even if $\epsilon$ were 0 , because profits have an income effect that reduce labor supply and thus still exacerbate pre-existing distortions.

Estimates for the elasticity of substitution in consumption, $\sigma_{\mathrm{Q}}$, are not available for the specific aggregation in our model between a "clean" good X and a "dirty" good Y. We choose a base value of 1.0 , which is broadly consistent with the empirical literature on substitution in consumption, and we test the sensitivity of results to alternative values. ${ }^{21}$

For $\phi$, we want an aggregate expenditure share for all goods with externalities in production or consumption. Based on 1993 data in the Statistical Abstract of the United States, the industries most responsible for pollution include chemical and paper producers, mining and primary metals, electric utilities, petroleum and coal production and processing, and motor vehicles and equipment. Total production by those industries constitutes almost $15 \%$ of GDP, so we use 0.15 for $\mathrm{Y} / \mathrm{L}{ }^{22}$ Since $\phi$ is defined as $\mathrm{Y} /\left[\mathrm{L}\left(1-\mathrm{t}_{\mathrm{L}}\right)\right]$, and since $\mathrm{t}_{\mathrm{L}}=0.4$, we must have $\phi=1 / 4$. In other words, these polluting goods are primarily private goods, so $15 \%$ of total output represents a quarter of private consumption.

Finally, we need a measure of marginal environmental damage $(\mu)$. Pearce and Turner (1990) review studies finding that damages from pollution are $0.5 \%$ to $0.9 \%$ of GNP in the Netherlands. Wicke (1990) reports estimates that are 6\% of GNP in Germany. Freeman (1982) estimates that pollution damages would be about $1.25 \%$ of GNP or higher in the U.S. in the absence of environmental polices. Unfortunately, none of these sources provide a measure of marginal damages. Based on the figures just mentioned, we assume

${ }^{21}$ For the next section, we also need an elasticity of substitution in production, $\sigma_{\mathrm{Y}}$. Again this parameter has not been estimated for our particular aggregation into two inputs. Caddy (1976) and Hamermesh (1993) provide extensive surveys of measured elasticities of substitution between capital and labor, and they each conclude that a value of 1 is reasonable. Berndt and Wood (1975) and others estimate translog KLEM production functions (for capital, labor, energy, and materials). We cannot use all of these cross-price elasticities directly in our model, because our first input is resources (which includes both labor and capital), and our other input is emissions (which is not the same as energy). Again we feel this literature is broadly consistent with a unitary elasticity of substitution, but we present results for other values as well.

${ }^{22}$ In any case, as shown in Goulder, Parry, and Burtraw (1996), results are not sensitive to this parameter. 
that total damages are $1.5 \%$ of total output. Then, since $\mathrm{Y}$ is $15 \%$ of total output, we have damages that are about $10 \%$ of $\mathrm{Y}$. Again we use two alternatives. If this relationship were linear, then damages would be about $10 \%$ of marginal output $(\mu=0.1)$. Given the tremendous uncertainty associated with this number, and the belief that marginal damages probably exceed the average, we also provide results for "treble damages" $(\mu=0.3)$. However, since $\mu$ enters linearly into the final welfare impact (eq. 24), readers can easily substitute any preferred value.

Table 1 shows the effects of a permit or CAC policy that mandates a small reduction in the quantity of the polluting good $(\hat{\mathrm{Y}}<0)$. The left-hand section show assumed values for some of the input parameters. The first four rows show results for $t_{L}=0.4$, while we vary $\epsilon$ and $\mu$. When marginal damage $\mu$ is 0.1 , then column 1 shows that a $1 \%$ reduction in $\mathrm{Y}$ yields benefits from reduced pollution that are $0.015 \%$ of national income. In the first row where $\epsilon$ is also 0.1 , and scarcity rents are not taxed $\left(\mathrm{t}_{\Pi}=0\right)$, we find that $\Delta=0.09$ (so a $1 \%$ reduction in output of $\mathrm{Y}$ induces a $0.09 \%$ reduction in labor supply). Multiplication by the tax rate $(0.4)$ yields a welfare cost from the labor supply reduction that is $0.036 \%$ of national income. Taking into account both the environmental gain (0.015) and the labor market loss $(-0.036)$, we find that the net effect is a reduction in welfare equal to $0.021 \%$ of national income. ${ }^{23}$

With a $40 \%$ tax on rents $\left(t_{\Pi}=t_{L}\right)$, where those revenues are used to reduce the labor tax rate, the labor market distortion falls from 0.036 to 0.023 . This latter figure still exceeds the 0.015 environmental gain, by 0.008 of national income. If we continued to increase the tax on rents, the loss from the labor distortion would continue to fall. In the limit, with $100 \%$ capture of scarcity rents $\left(t_{\Pi}=1\right)$, then labor supply is unaffected. An environmental policy that collects all of the scarcity rents can eliminate the negative effects on the preexisting labor distortion. This policy can have unambiguously positive effects on welfare. ${ }^{24}$ Notice, however, that $100 \%$ capture is necessary just to get the whole first dividend -- from

${ }^{23}$ Because this permit or CAC policy leaves the scarcity rents in private hands, it is equivalent to a policy that imposes an environmental $\operatorname{tax}$ on $\mathrm{Y}$ and then uses the revenue for a lump sum transfer to households (instead of using the revenue to reduce the labor tax rate). Such an environmental tax policy reduces welfare just like the permit or CAC policy.

${ }^{24}$ This case with $t_{\Pi I}=1$ corresponds exactly to the case of Bovenberg and de Mooij (1994) where a tax on the dirty good generates revenues used to reduce the tax on labor income. See equation (13) in their paper, when their initial $t_{D}$ equals 0 . 
Table 1

Welfare Effect of a Small Cut in Pollution:

Fixed Pollution per Unit of Output

\begin{tabular}{|c|c|c|c|c|c|c|c|c|}
\hline \multirow{2}{*}{\multicolumn{4}{|c|}{$\begin{array}{c}\text { Assumed Parameter } \\
\text { Values }\end{array}$}} & \multirow{3}{*}{$\begin{array}{c}\text { Gain from } \\
\text { Externality } \\
\text { Correction } \\
(1) \\
\mu(\mathrm{Y} / \mathrm{L}) \\
\end{array}$} & \multicolumn{2}{|c|}{$t_{\Pi}=0$} & \multicolumn{2}{|c|}{$t_{\mathrm{II}}=\mathrm{t}_{\mathrm{L}}$} \\
\hline & & & & & $\begin{array}{l}\text { Loss from } \\
\text { Labor } \\
\text { Distortion }\end{array}$ & $\begin{array}{l}\text { Net Effect } \\
\text { on Welfare }\end{array}$ & $\begin{array}{l}\text { Loss from } \\
\text { Labor } \\
\text { Distortion }\end{array}$ & $\begin{array}{l}\text { Net Effect } \\
\text { on Welfare }\end{array}$ \\
\hline$t_{L}$ & $\epsilon$ & $\mu$ & $\mathrm{Y} / \mathrm{L}$ & & $\mathrm{t}_{\mathrm{L}}\left(1-\mathrm{t}_{\Pi}\right) \Delta$ & $\psi$ & $\mathrm{t}_{\mathrm{L}}\left(1-\mathrm{t}_{\Pi}\right) \Delta$ & $\psi$ \\
\hline .4 & .1 & .1 & 0.15 & 0.015 & 0.036 & -0.021 & 0.023 & -0.008 \\
\hline .4 & .3 & .1 & 0.15 & 0.015 & 0.062 & -0.047 & 0.041 & -0.026 \\
\hline .4 & .1 & .3 & 0.15 & 0.045 & 0.036 & 0.009 & 0.023 & 0.022 \\
\hline .4 & .3 & .3 & 0.15 & 0.045 & 0.062 & -0.017 & 0.041 & 0.004 \\
\hline .3 & .3 & .3 & 0.18 & 0.053 & 0.045 & 0.007 & 0.034 & 0.019 \\
\hline .5 & .3 & .3 & 0.13 & 0.038 & 0.081 & -0.043 & 0.048 & -0.011 \\
\hline
\end{tabular}

The four parameters in the first part of the table are: tax rate on labor income $\left(t_{L}\right)$, uncompensated labor supply elasticity $(\epsilon)$, social marginal damage of pollution $(\mu)$, and the production of the dirty good as a fraction of total output $(\mathrm{Y} / \mathrm{L})$. Other parameter values are as follows: elasticity of substitution in consumption $\left(\sigma_{Q}\right)$ equals 1.0 , income elasticity of labor supply $(\eta)$ equals -0.2 , and the expenditure share of the dirty good in consumption $(\phi)$ equals 0.25 . See text for details. 
the environment.

The second row of Table 1 changes the labor supply elasticity from 0.1 to 0.3 , so the negative effect on labor is enlarged. Welfare falls even more. The point is that when environmental controls raise production costs, the lower real net wage can reduce effort on the job, induce secondary workers to quit, or even shift the same effort from taxable to nontaxable forms like home production or the underground economy. As taxable labor supply becomes more responsive, the environmental policy is less likely to raise welfare.

The next two rows triple the marginal environmental damage (from 0.1 to 0.3 ). If the labor supply elasticity is back down to 0.1 , then the environmental gain $(0.045)$ exceeds the loss from the labor distortion (0.036). Even with "treble damages," this policy just barely raises welfare (by 0.009 ). Still, however, the taxation of scarcity rents can reduce the labor market loss and leave more of the environmental gain.

When both parameters are 0.3 , the large environmental gain $(0.045)$ is more than offset by the larger loss from labor distortions $(0.062)$ when scarcity rents are untaxed. Since the environmental gain ( $\mu \mathrm{Y} / \mathrm{L}$ ) is linear in $\mu$, it is easy to calculate that the marginal external damage would have to be over $40 \%$ of the firm's production cost for this environmental regulation to break even in terms of welfare. In particular examples, the externality might well be high, perhaps over $100 \%$ of the firm's production cost. The point remains, however, that even a large gain from correcting a large externality can be offset by losses from labor market distortions -- unless the government captures the scarcity rents. In the fourth row (where both parameters are 0.3 ), the $40 \%$ tax on rents converts the net loss (-0.017) into a small net gain (0.004).

The last three rows of Table 1 illustrate the effect of altering the initial labor tax rate (keeping $\epsilon$ and $\mu$ at 0.3). Consider column 3 (where $t_{\Pi}=0$ ). If $t_{L}$ is 0.3 , instead of 0.4 , the net welfare effect is a small net gain $(0.007)$ instead of a loss $(-0.017) .{ }^{25}$ Note, however, that this 0.007 net gain is still only a small fraction of the 0.053 gain possible with government capture of the rents. If the initial tax rate is raised to 0.50 , then the welfare loss is increased from -0.017 to -0.043 . If scarcity rents are not taxed and the tax on labor income is $50 \%$, then the marginal environmental damage $(\mu)$ would have to be over $60 \%$ of production cost before the regulatory policy could begin to improve welfare.

\footnotetext{
${ }^{25}$ When we change $t_{L}$ from 0.4 to 0.3 , we assume that $\phi$ remains at $1 / 4$, so $Y / L$ $=\phi\left(1-t_{\mathrm{L}}\right)$ must change (from 0.15 to 0.18 ).
} 
A permit policy like the Clean Air Act Amendments of 1990 creates a scarcity rent that is left in private hands. It does not necessarily improve welfare, in this second-best world, even when starting with a substantial uncorrected externality.

\section{Model and Results with Variable Pollution per Unit Output}

We now allow for factor substitution in the production of $Y$. The welfare impact of an environmental regulation still depends on how labor supply is affected, and equation (23) still provides us the effect on labor supply from a change in output of $Y$. The remaining step is to show the effect on $\mathrm{Y}$ of a mandated change in emissions.

Let $\sigma_{Y}$ represent the elasticity of substitution in production of $Y$ between the two inputs $\left(L_{Y}\right.$ and $\left.Z\right)$. Then, by definition:

$$
\hat{\mathrm{L}}_{\mathrm{Y}}-\hat{\mathrm{Z}}=\sigma_{\mathrm{Y}}\left(\hat{\mathrm{p}}_{\mathrm{Z}}-\hat{\mathrm{p}}_{\mathrm{L}}\right)
$$

The price of the labor is fixed, however, so equation (25) can be written as:

$$
\hat{\mathrm{L}}_{\mathrm{Y}}=\hat{\mathrm{Z}}+\sigma_{\mathrm{Y}} \hat{\mathrm{p}}_{\mathrm{Z}}
$$

We showed above that $d Y=d L_{Y}+d Z$ (eq. 8), so the percentage change in output of $Y$ can be expressed as a weighted average of the percentage changes in the two inputs:

$$
\hat{\mathrm{Y}}=\left(\frac{\mathrm{L}_{\mathrm{Y}}}{\mathrm{Y}}\right) \hat{\mathrm{L}}_{\mathrm{Y}}+\left(\frac{\mathrm{Z}}{\mathrm{Y}}\right) \hat{\mathrm{Z}}
$$

Recall that the firm makes zero profits on output, given the raised price of emissions necessary to cover the scarcity rents, so:

$$
\mathrm{p}_{\mathbf{Y}} \mathrm{Y}=\mathrm{p}_{\mathbf{L}} \mathrm{L}_{\mathbf{Y}}+\mathrm{p}_{\mathbf{Z}} \mathrm{Z}
$$

Evaluated at initial prices of one (prior to the regulation), we have $\mathrm{Y}=\mathrm{L}_{\mathrm{Y}}+\mathrm{Z}$. Substitute eq. (26) into (27) and use the relationship $Y=L_{Y}+Z$ to obtain:

$$
\hat{\mathrm{Y}}=\hat{\mathrm{Z}}+\sigma_{\mathrm{Y}}\left(\frac{\mathrm{L}_{\mathrm{Y}}}{\mathrm{Y}}\right) \hat{\mathrm{p}}_{\mathrm{Z}}
$$

Now recall that the full equilibrium effect on $Y$, in equation (22), is $\hat{Y}=\gamma_{Y} \hat{p}_{Y} \cdot A$ 
footnote after eq. (15) derives $\hat{\mathrm{p}}_{\mathrm{Y}}=(\mathrm{Z} / \mathrm{Y}) \hat{\mathrm{p}}_{\mathrm{Z}}$. Together, these two relationships imply:

$$
\hat{\mathrm{p}}_{\mathrm{Z}}=\left(\frac{\mathrm{Y}}{\mathrm{Z} \gamma_{\mathrm{Y}}}\right) \hat{\mathrm{Y}}
$$

Substituting (30) into (29) provides the equilibrium relationship between $\mathrm{Y}$ and $\mathrm{Z}$ :

$$
\hat{\mathrm{Y}}=\left(\frac{\gamma_{\mathrm{Y}}}{\gamma_{\mathrm{Y}}-\left(\frac{\mathrm{L}_{\mathrm{Y}}}{\mathrm{Z}}\right) \sigma_{\mathrm{Y}}}\right) \hat{\mathrm{Z}}
$$

Note, by the way, that $\mathrm{L}_{\mathrm{Y}}=0$ means that $\hat{\mathrm{Y}}=\hat{\mathrm{Z}}$, for all results in the previous section. Finally, we substitute eq. (31) into (23) and use the expression for $\gamma_{Y}$ to get:

$$
\hat{\mathrm{L}}=\left(1-\mathrm{t}_{\Pi}\right)\left\{\frac{\left(1-\mathrm{t}_{\mathrm{L}}\right) \phi(\eta-\epsilon)}{\left(1-\mathrm{t}_{\Pi}\right) \phi(\eta-\epsilon)-\left[\sigma_{Q}(1-\phi)+\sigma_{Y}\left(L_{Y} / Z\right)\right]\left(1-t_{L}-\epsilon t_{L}\right)}\right\} \hat{Z} \equiv\left(1-t_{\Pi}\right) \Omega \hat{Z}
$$

Expression (24) for the welfare effects of the policy now becomes:

$$
\frac{\mathrm{dU}}{\lambda \mathrm{L}}=\left(\mathrm{t}_{\mathrm{L}}\left(1-\mathrm{t}_{\Pi}\right) \Omega-\mu\left(\frac{\mathrm{Z}}{\mathrm{L}}\right)\right) \hat{\mathrm{Z}} \equiv-\psi \hat{\mathrm{Z}}
$$

This expression redefines the net effect on welfare, $\psi$, for the more general case with variable emissions per unit output. Under what circumstances does this expression reduce to the previous one for fixed emissions? To help interpret these expressions, we note some special cases.

First, if $t_{\Pi}=1$, then again $\hat{\mathrm{L}}$ in (32) is zero. In this case a pollution tax is used to collect revenue for use in reducing the labor tax. This policy has no effect on labor distortions, and the only welfare effect is the unambiguous gain from correcting the externality $(\mu \mathrm{Z} / \mathrm{L})$.

Second, consider the case where $\sigma_{\mathrm{Y}}=0$. Then equation (32) shows how $\Omega$ collapses to $\Delta$. Also, because of fixed coefficient production, $\hat{\mathrm{Y}}=\hat{\mathrm{Z}}$. This case is not quite comparable to the previous case, however, because $\mathrm{Z}$ is only part of the production of $\mathrm{Y}$. If the externality arises only from $\mathrm{Z}$, and not from all of $\mathrm{Y}$, then the gain from correcting the externality $(\mu \mathrm{Z} / \mathrm{L})$ is effectively cut from its previous size $(\mu \mathrm{Y} / \mathrm{L})$. The loss from exacerbating labor supply distortions $\left[t_{L}\left(1-t_{\Pi}\right) \Omega\right]$ is the same as before, so the net loss of welfare is larger than before. 
Third, instead, suppose $L_{Y}=0$. Then $Y=Z$, so $\hat{Y}=\hat{Z}$, and equation (32) also shows that $\Omega$ reduces to $\Delta$. In this case, regardless of $\sigma_{Y}$, all numerical results must match the previous results. But this case is not "variable emissions per unit of output."

Fourth, however, we can still construct a case with variable emissions that will have results comparable to those of the previous model. We want pollution in the new model (Z) to be the same size as pollution in the old model (Y), so we double the size of $\mathrm{Y}$ while assuming that half of its input is $Z$. In other words, we set $L_{Y}=Z$, and double the share of $\mathrm{Y}$ in consumption, $\phi$, from 0.25 to 0.50 . Numerical results are shown in Table 2 .

Again we consider a permit or CAC policy that mandates a small reduction in pollution $(\hat{Z}<0)$. The assumed parameter values all match the case above (where $t_{L}=0.4$, and $\epsilon=\mu=0.3$, but $\phi=0.50$ in order for $Z / L$ to match the previous $Y / L$ at 0.15 ). Also, we now have the additional parameter, $\sigma_{\mathrm{Y}}$. This parameter measures the ability to substitute clean inputs for dirty inputs. Because the size of this elasticity is so uncertain, we consider a number of values. Table 2 varies this parameter from zero to 2.0 , and can be used to demonstrate several points.

First, in column 2 , note that the welfare loss from this environmental regulation falls as the degree of factor substitutability $\left(\sigma_{Y}\right)$ rises. The regulation is simply not as costly when emissions can more readily be avoided by using the other input instead. When factors are used in fixed proportions, and the government mandates a $1 \%$ cut in emissions, then the efficiency loss from the labor distortion is $0.122 \%$ of national income. When the elasticity is increased to 0.5 , this loss is reduced by $30 \%$. Doubling the elasticity to 1.0 , or again to 2.0, provide further reductions in the welfare loss. The net loss in column 3 changes to a small net gain. A similar story holds for the case where scarcity rents are taxed at $40 \%$.

Second, look at the third row with $\sigma_{\mathrm{Y}}=1$. These results exactly match the corresponding case in our previous model (row 4 of Table 1). To explain this equivalence, note that the elasticity of substitution in consumption $\left(\sigma_{\mathrm{Q}}\right)$ is also set equal to one. Thus all expenditure shares are unchanged by policy shocks. Consumers do not change the fraction of income spent on $\mathrm{Y}$, and producers of $\mathrm{Y}$ do not change the fraction of sales revenue spent on each input. The economy-wide fraction of income spent on pollution was set to 0.15 for both models, and this overall share is unchanged by policy, so the two models are functionally equivalent.

Third, as we showed in the previous section using "plausible" parameter values, the mandated reduction in pollution has a cost from worsening the labor distortion that offsets 
Table 2

Welfare Effect of a Small Cut in Pollution:

Variable Pollution per Unit of Output

\begin{tabular}{|c|c|c|c|c|c|}
\hline & \multirow[b]{2}{*}{$\begin{array}{c}\text { Gain from } \\
\text { Externality } \\
\text { Correction } \\
\text { (1) }\end{array}$} & \multicolumn{2}{|c|}{$\mathrm{t}_{\Pi}=0$} & \multicolumn{2}{|c|}{$\mathrm{t}_{\Pi}=\mathrm{t}_{\mathrm{L}}$} \\
\hline & & $\begin{array}{l}\text { Loss from } \\
\text { Labor } \\
\text { Distortion } \\
\text { (2) }\end{array}$ & $\begin{array}{c}\text { Net Effect } \\
\text { on Welfare } \\
\text { (3) }\end{array}$ & $\begin{array}{l}\text { Loss from } \\
\text { Labor } \\
\text { Distortion } \\
\text { (4) }\end{array}$ & $\begin{array}{c}\text { Net Effect } \\
\text { on Welfare } \\
\text { (5) }\end{array}$ \\
\hline$\sigma_{\mathrm{Y}}$ & $\mu(\mathrm{Z} / \mathrm{L})$ & $\mathrm{t}_{\mathrm{L}}\left(1-\mathrm{t}_{\Pi}\right) \Omega$ & $\psi$ & $\mathrm{t}_{\mathrm{L}}\left(1-\mathrm{t}_{\Pi}\right) \Omega$ & $\psi$ \\
\hline 0.00 & 0.045 & 0.122 & -0.077 & 0.092 & -0.047 \\
\hline 0.50 & 0.045 & 0.082 & -0.037 & 0.057 & -0.012 \\
\hline 1.00 & 0.045 & 0.062 & -0.017 & 0.041 & 0.004 \\
\hline 2.00 & 0.045 & 0.041 & 0.004 & 0.027 & 0.018 \\
\hline
\end{tabular}

The parameter in the first part of the table is the elasticity of substitution in production $\left(\sigma_{\mathrm{Y}}\right)$. Other parameter values are as follows: tax rate on labor income $\left(t_{L}\right)$ equals 0.4 , uncompensated labor supply elasticity $(\epsilon)$ equals 0.3 , social marginal damage of pollution $(\mu)$ equals 0.3 , elasticity of substitution in consumption $\left(\sigma_{Q}\right)$ equals 1.0 , income elasticity of labor supply $(\eta)$ equals -0.2 , and the expenditure share of the dirty good in consumption $(\phi)$ equals 0.5 . See text for details. 
most or all of the gain from starting to fix the pollution problem. Results in this section show that this conclusion is not reversed by allowing for any reasonable degree of substitutability in production between clean inputs and dirty inputs.

\section{An Environmental Subsidy}

So far, our results seem to suggest that environmental policy needs to raise revenue in order to be able to reduce the labor tax and avoid exacerbating the pre-existing labor supply distortion. Perhaps policies could be ordered by their revenue effects. After all, the environmental tax can provide unambiguous welfare gains, while the mandated restrictions on emissions that does not raise revenue usually provides a net welfare loss. One might think that an environmental subsidy would rank lowest, in terms of welfare, since the government must balance its budget and cover the cost of the subsidy by raising the tax on labor.

Perhaps surprisingly, these next two sections show that this logic is faulty. The policy does not need to raise revenue in order to achieve the maximum net welfare gain. Even the environmental subsidy can have the positive effect of improving the environment without the negative effect on the labor supply distortion. Rather than keeping track of revenues, per se, we need to keep track of general equilibrium effects on the real net wage.

To demonstrate this point most clearly for an environmental subsidy, we revert temporarily to the simple model with $Y=Z$. We then consider a subsidy (s) to the consumption of the clean good $(\mathrm{X})$, financed by an increase in the tax on labor. The individual budget constraint becomes $X(1-s)+p_{Y} Y=\left(1-t_{L}\right) L$. This policy tilts the consumer toward purchase of $\mathrm{X}$, and therefore away from $\mathrm{Y}$. The output $\mathrm{Y}$ is produced using only the single resource, which is numeraire, so changes in the output of $\mathrm{Y}$ do not affect its price. With competition among firms, the policy generates no pure profits, and the government budget in equation (11) becomes:

$$
\mathbf{G}=\mathrm{Nt}_{\mathbf{L}} \mathrm{L}-\mathrm{NsX}
$$

where the initial $s$ is zero. We differentiate, holding $G$ constant, to get:

$$
\hat{\mathrm{t}}_{\mathrm{L}}=-\left(\frac{\mathrm{t}_{\mathrm{L}}}{1-\mathrm{t}_{\mathrm{L}}}\right) \hat{\mathrm{L}}+(1-\phi) \hat{\mathrm{s}}
$$

where $\hat{s}=d s /(1-s)$. The real net wage is $w=\left(1-t_{L}\right) / p_{Q}$, where $p_{Q}=\phi p_{Y}+(1-\phi)(1-s)$. The price of $\mathrm{Y}$ does not change, so $\mathrm{dp}_{\mathrm{Q}}=(1-\phi)(-\mathrm{ds})$. Thus, differentiating $\mathrm{w}$ yields: 


$$
\hat{\mathrm{w}}=-\hat{\mathrm{t}}_{\mathrm{L}}+(1-\phi) \hat{\mathrm{s}}
$$

Substitute (12') into equation (15') to get:

$$
\hat{\mathrm{w}}=\left(\frac{\mathrm{t}_{\mathrm{L}}}{1-\mathrm{t}_{\mathrm{L}}}\right) \hat{\mathrm{L}}
$$

Since profits are zero, the labor supply function is $\mathrm{L}=\mathrm{L}(\mathrm{w}, 0)$, and (18) reduces to:

$$
\hat{\mathbf{L}}=\epsilon \hat{\mathbf{w}}
$$

As long as the initial point is not at the peak of the Laffer curve, where $\epsilon=\left(1-t_{\mathrm{L}}\right) / t_{\mathrm{L}}$, these last two equations imply that $\hat{\mathrm{w}}=\hat{\mathrm{L}}=0$. This result is important, because overall welfare in equation (24) depends on both a labor supply effect and the environmental quality effect. This policy has no effect on the real net wage, and therefore no effect on the pre-existing labor supply distortion. It has only the positive effect from improving the environment.

This point also warrants some elaboration. The key is not that the environmental policy raise revenue, but that it avoid adverse effects on the real net wage. The environmental tax raises product prices, and would thus reduce the real net wage unless the revenue is used to reduce the labor tax. Symmetrically, the environmental subsidy would reduce product prices, and raise the real net wage, except that it requires the government to acquire the necessary revenue by raising the labor tax. Indeed, when properly specified, neither of these policies raise revenue! One policy is a revenue-neutral combination of a new environmental tax plus reduction in the labor tax, and the other policy is a revenueneutral combination of an environmental subsidy plus increase in the labor tax. Neither combination affects the real net wage in this model. The problem with the handout of permits and the restrictive CAC policy is that they raise the cost of production without providing an offsetting effect on the labor tax rate.

These results carry through to the case with variable emissions. The analogous subsidy in this case would induce the firm to shift the mix of inputs away from emissions and into the clean input. The subsidy to clean inputs would reduce the cost of production, and therefore the equilibrium price of output, so it would encourage more purchase of the good produced using emissions. However, the subsidy to the clean input can be financed by 
introducing a tax on output of Y. Analogous derivations show that this policy balances the government's budget while leaving the consumer's price of $\mathrm{Y}$ unchanged. Thus the real net wage and labor supply are unchanged. In fact, as shown in Fullerton and Wolverton (1997), each environmental tax has an equivalent two-part instrument. Any tax on waste may be difficult to enforce, and it can always be replaced by an equivalent combination of a presumptive tax on production plus an environmental subsidy.

To further clarify that revenue-raising is not the important issue, consider a revenueneutral combination of a subsidy to the clean input and tax on the dirty input. Is this policy a tax that raises revenue (used to finance a subsidy), or is it a subsidy (financed by using a $\operatorname{tax})$ ? The question is not relevant. In this model, for small changes, this two-part instrument shifts the mix of inputs with no effect on output price and thus no effect on labor supply. The result is an unambiguous increase in welfare from the environment. In fact, as shown in the next section, a mandated change in the mix of inputs is equivalent to this revenue-neutral two-part policy of incentives to shift the mix of inputs.

\section{Technology Restrictions}

Do all command and control policies raise production costs and exacerbate the labor supply distortion? Environmental authorities can choose among a number of different kinds of controls. If they hand out a limited number of permits, or otherwise just restrict the quantity of emissions, they create a scarce resource. Whoever owns the "rights" to those limited emissions earns a scarcity rent. If those profits do not accrue to the government, we showed above that the policy does exacerbate labor supply distortions. Similarly, a "new source performance standard" erects a barrier to entry by raising costs for new firms only. Suppose instead, however, that the authorities were to impose a technological requirement on the production process for all firms. For example, suppose every firm must have a scrubber on every smokestack. This rule might raise costs, but it does not restrict entry, it does not provide an advantage to existing firms, and it does not limit the quantity of emissions. It cannot generate profits in our model, because other firms have access to the exact same constant-returns-to-scale technology and would enter to share those profits.

This kind of technological restriction can be analyzed in our model as a forced change in emissions $(Z)$ per unit of output $(Y)$, or equivalently, a forced change in the ratio

of inputs $\left(\mathrm{L}_{\mathrm{Y}} / \mathrm{Z}\right)$. In other words, instead of the policy $\hat{Z}<0$, we analyze the policy $\left(\hat{\mathrm{L}}_{\mathrm{Y}}-\hat{\mathrm{Z}}\right)>0$. Firms have a number of ways to comply with this restriction. They can cut emissions, or they can just use more of the clean input. They could even increase emissions, 
so long as they increase clean inputs (and thus output) more than proportionately. In order to look at the firm's problem in terms of levels, rather than changes, suppose the initial equilibrium quantities are $\mathrm{Y}^{0}=\mathrm{F}\left(\mathrm{L}_{\mathrm{Y}}{ }^{0}, \mathrm{Z}^{0}\right)$. Then the new policy restricts the choice of $\mathrm{L}_{Y}$ and $\mathrm{Z}$ such that

$$
\left(\frac{\mathrm{L}_{\mathrm{Y}}}{\mathrm{Z}}-\frac{\mathrm{L}_{\mathrm{Y}}^{0}}{\mathrm{Z}^{0}}\right) \geq \mathrm{r}>0
$$

The initial ratio of inputs $\left(\mathrm{L}_{Y}^{0} / Z^{0}\right)$ is taken as given by policy makers, existing firms, and even potential entrants. ${ }^{26}$ Policy makers specify the required increase in that ratio (r). Any existing firm or entrant takes those two parameters $\left(\mathrm{L}_{\mathbf{Y}}^{0} / \mathrm{Z}^{0}\right.$ and $\left.\mathrm{r}\right)$ as given.

The initial equilibrium has no restriction $(r=0)$, and we find a new equilibrium with a small increase in $r$. In particular, we want to know if this restriction helps the environment more than it exacerbates the labor supply distortion. Perhaps surprisingly, we find that a small increase in $r$ has no effect on production costs and therefore no effect on the price of $Y$. As a consequence, it has no effect on the real net wage or the pre-existing labor supply distortion. In general, the firm chooses $\mathrm{L}_{\mathrm{Y}}$ and $\mathrm{Z}$ to minimize:

$$
\mathscr{L}=\mathrm{p}_{\mathrm{L}} \mathrm{L}_{\mathrm{Y}}+\mathrm{p}_{\mathrm{Z}} \mathrm{Z}+\xi_{1}\left[\mathrm{Y}-\mathrm{F}\left(\mathrm{L}_{\mathrm{Y}}, \mathrm{Z}\right)\right]+\xi_{2}\left(\mathrm{r}-\left(\frac{\mathrm{L}_{\mathrm{Y}}}{\mathrm{Z}}-\frac{\mathrm{L}_{\mathrm{Y}}^{0}}{\mathrm{Z}^{0}}\right)\right)
$$

Define $C^{*}$ as the optimized cost function. By the envelope theorem, $\xi_{1}$ is the marginal cost of production $\left(\partial \mathrm{C}^{*} / \partial \mathrm{Y}\right)$ while $\xi_{2}$ is the shadow price of the regulatory constraint $\left(\partial C^{*} / \partial r\right)$. We want to know how the policy $(r)$ affects the marginal cost of production $\left(\xi_{1}\right)$, that is, the magnitude of $\mathrm{d} \xi_{1} / \mathrm{dr}$. Second partials are invariant to the order of differentiation, so:

$$
\frac{\partial^{2} \mathrm{C}^{*}}{\partial \mathrm{Y} \partial \mathrm{r}}=\frac{\partial \xi_{1}}{\partial \mathrm{r}}=\frac{\partial \xi_{2}}{\partial \mathrm{Y}}
$$

Thus, to see how marginal cost changes with $r$, we need only consider how the shadow

${ }^{26}$ Because of constant returns to scale, in this model, the same ratio of inputs would be used by all firms. The ratio matters, but not the initial level of each input. 
price on the regulatory constraint changes with $Y$. At the initial point where $r=0$, and therefore the initial $\xi_{2}=0$, constant returns to scale in $F\left(L_{Y}, Z\right)$ implies that output $Y$ can vary with no change in the factor ratio (given factor prices). In other words, changes in $\mathrm{Y}$ have no impact on $\xi_{2}$. Since $\mathrm{d} \xi_{2} / \mathrm{dY}=0$ at that point, equation (36) implies that $\mathrm{d} \xi_{1} / \mathrm{dr}$ $=0$. And with competition among firms, no change in marginal cost means no change in output price. Thus the policy does not affect the real net wage.

In the absence of profits, labor supply is $\hat{\mathrm{L}}=\epsilon \hat{\mathrm{W}}=0$. Also, since the price of $\mathrm{Y}$ is unchanged, the demand for $\mathrm{Y}$ must be unchanged. Essentially, firms switch from $\mathrm{Z}=\mathrm{L}_{\mathrm{Z}}$ into $\mathrm{L}_{\mathrm{Y}}$ with no change in total use of resources $\mathrm{L}$, and no change in output. But then we know that $Z$ falls, so the welfare effect in (9) reduces to:

$$
\frac{\mathrm{dU}}{\lambda \mathrm{L}}=-\mu\left(\frac{\mathrm{Z}}{\mathrm{L}}\right) \hat{\mathrm{Z}}>0 .
$$

These results may seem surprising: how can an environmental restriction leave the marginal cost of production unchanged? To provide some intuition on this question, Figure 1 shows how the optimized cost function $C^{*}$ is related to the regulatory parameter $r$. Because of constant returns to scale, this total cost can be taken for one unit of output and interpreted as marginal cost. This cost per unit output is minimized by the firm's unrestricted choices at the initial point where $r=0$, so it must be higher at any $r \neq 0$.

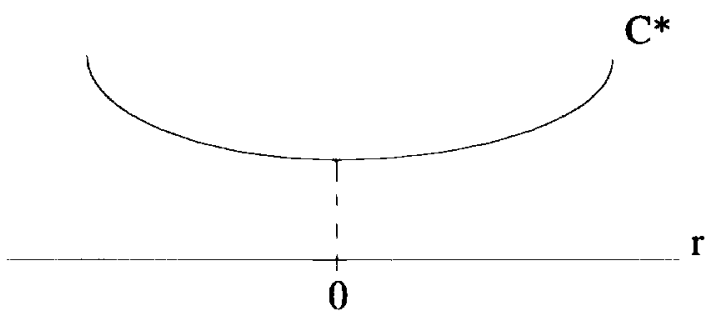

Figure 1. Marginal Cost and Regulation

Thus costs are higher with $r \neq 0$, as one would expect. But, evaluated at $r=0$, the curve is flat. From the initial starting point, a small change in $r$ has no perceptible effect on cost. As the policy becomes restrictive, however, it would begin to raise the cost of production. 
Since the marginal cost of environmental protection is the increment to production cost, we have just shown that the marginal cost curve for this type of environmental protection starts at the origin. A small but finite restriction has only second-order effect on cost, but it has first-order effect on environmental benefits (since $\mu$ is strictly positive). We do not find the optimal degree of protection, that is, where the rising marginal cost curve intersects the falling marginal benefit curve. We only show that, for positive initial marginal benefits of protection, the first small restriction unambiguously raises welfare. ${ }^{27}$

In a way, these considerations make the prior results more surprising. What we showed above is that a small restriction on emissions $\hat{\mathrm{Z}}<0$ does have an impact on cost. Because the firm must cover the scarcity rent on every unit of emissions, production become more expensive. The profits are not dissipated, because entry is limited by the fixed limit on emissions. In contrast, the technology restriction $\left(\hat{\mathrm{L}}_{\mathbf{Y}}-\hat{\mathrm{Z}}\right)>0$ has two parts, and no absolute limit on emissions. These two parts generate a sort of cross-subsidy within the firm. Emissions may be reduced, such that the marginal product $\mathrm{F}_{\mathrm{Z}}$ rises above private cost $\left(p_{Z}=1\right)$, but, to produce the same output, labor is increased such that its marginal product $\mathrm{F}_{\mathrm{L}}$ falls below private cost $\left(\mathrm{p}_{\mathrm{L}}=1\right)$. Implicitly, profits on emissions are offset by losses on use of labor, as necessary to satisfy the restriction, with no net profits.

Thus the technology restriction is equivalent to the revenue-neutral combination of the small environmental tax on $Z$ and subsidy to $L_{Y}$. In one case the government collects the "profits" on $\mathrm{Z}$ to cover "losses" on $\mathrm{L}_{\boldsymbol{\gamma}}$, and in the other case the government forces the firm to use profits on $Z$ to cover its own losses on $L_{Y}$. The two outcomes are equivalent. Again, this result clarifies that the important distinction is not whether the policy raises revenue, but whether it generates privately-retained rents.

\section{Model and Results with Monopoly Production}

To this point, we have assumed that all markets are perfectly competitive, but we now explore how environmental policies affect welfare in the presence of imperfect competition. To be specific, we consider the case where the polluting good $(\mathrm{Y})$ is provided

${ }^{27}$ This technological restriction is perfectly efficient in our model, like the pollution tax or sale of permits (with revenue used to reduce the labor tax). However, our model does not capture differences among firms' abatement cost functions. If these costs differ, then to remain as efficient as a tax or permit policy, a technology-based CAC policy would have to specify which firms must change which technologies. Information problems may become prohibitive. Also, the pollution tax might provide more dynamic efficiency through incentives to invent new technologies. 
by a monopolist. ${ }^{28}$ In all other regards, we maintain the model developed in the previous sections. However, to keep the analysis simple, we revert to the fixed-emissions model in which $\mathrm{Y}$ is produced using only labor $(\mathrm{Y}=\mathrm{Z})$. Our economy now has three pre-existing distortions: a wage tax, a monopolist, and an uncorrected externality. As a consequence, the welfare effect of any particular change cannot be known a priori. The initial equilibrium production of $\mathrm{Y}$ may be too low because of the monopolist, or too high because of the externality. Similarly, even the initial labor supply may be above or below the welfaremaximizing level. Any environmental policy that requires a reduction in $\mathrm{Y}$ will alleviate some problems and exacerbate others. We solve for the general equilibrium effect of a small policy on all three distortions.

The production relationships are linear as in our first model above. The household budget constraint is still given by (14), but after-tax monopoly profits $\left(1-t_{\Pi I}\right) \Pi$ exist prior to the implementation of any environmental policy. These profits are defined by:

$$
\Pi=\left(\mathrm{p}_{\mathrm{Y}}-1\right) \mathrm{Y}
$$

The firm maximizes these profits by choosing $\mathrm{Y}$ (or equivalently $\mathrm{p}_{\mathrm{Y}}$, given the demand curve). We define $\epsilon_{\mathrm{Y}}$ as the absolute value of the price elasticity of demand for $\mathrm{Y}$, so the firm's first-order condition is:

$$
p_{Y}-1=\frac{p_{Y}}{\epsilon_{Y}}
$$

The degree to which the price of $\mathrm{Y}$ exceeds marginal cost depends on the elasticity of demand for $\mathrm{Y}$. The higher is $\epsilon_{\mathrm{Y}}$, the less distortion is created by having a monopoly in the production of Y. Equation (38) can only be satisfied if the monopolist produces in the portion of the demand curve where the elasticity is greater than one. ${ }^{29}$

${ }^{28}$ Barnett (1980) also considers a Pigouvian tax in the case where a monopolist generates pollution. In his partial equilibrium model, he does not consider other distortions. Another possibility is monopoly in the clean sector, $X$. Then the regulatory reduction in $\mathrm{Y}$ will tend to offset the monopolist's reduction in $\mathrm{X}$, but reinforce the wage tax effect of reducing both goods relative to leisure. We leave these questions for future research.

${ }^{29}$ We set parameters below such that the initial $\mathrm{p}_{\mathrm{Y}}$ is 1.2 , so profits are $20 \%$ of the cost of producing $\mathrm{Y}$, but then (38) implies that $\epsilon_{\mathrm{Y}}$ is six. We also derive the corresponding value of $\sigma_{Q}$, which also must exceed one. 
Totally differentiating the definition of profits in (37), and using the first order condition for the monopolist in (38) yields:

$$
\hat{\Pi}=\hat{\mathbf{Y}}+\epsilon_{\mathrm{Y}} \hat{\mathrm{p}}_{\mathrm{Y}}
$$

Also, along a demand curve where income and other prices are constant, the consumer's behavior is defined by:

$$
\hat{\mathbf{Y}}=-\epsilon_{\mathrm{Y}} \hat{\mathrm{p}}_{\mathrm{Y}}
$$

The firm uses the demand curve in (40) to arrive at its maximizing behavior in (39), so substitution yields $\hat{\Pi}=0$. That is, the firm cannot increase profits by movement in either direction along the demand curve. We use (39) to calculate a change in profits that is not zero, however, for an environmental regulation that shifts the demand curve by changing income and other prices. Also, occasionally, it will be useful to write profits as:

$$
\Pi=\left(p_{Y}-1\right) Y=\frac{p_{Y} Y}{\epsilon_{Y}} .
$$

where the first equality reflects the definition of profits in (37) and the second equality reflects the firm's behavior in (38). The far right expression for profits is written in terms of $\epsilon_{\mathrm{Y}}$, the demand elasticity for $\mathrm{Y}$. This elasticity can be expressed as a function of $\sigma_{\mathrm{Q}}$, defined in equation (20) as the elasticity of substitution between the two consumption goods. ${ }^{30}$ Differentiating the household budget constraint (holding income constant) yields:

$$
\hat{\mathrm{X}}=-\frac{\phi}{1-\phi}\left(\hat{\mathrm{Y}}+\hat{\mathrm{p}}_{\mathrm{Y}}\right) \text {. }
$$

Then, combining equations (20), (40), and (42) yields:

$$
\epsilon_{\mathrm{Y}}=\phi+(1-\phi) \sigma_{\mathrm{Q}}
$$

${ }^{30}$ Since utility is separable between consumption and leisure, we can express preferences between the two goods either in terms of the price elasticity of demand for one of the goods or in terms of the elasticity of substitution between $X$ and $Y$. To be consistent with our earlier models, we choose $\sigma_{Q}$ as our behavioral parameter. 
Since $\epsilon_{\mathrm{Y}}$ must exceed 1 , the monopoly solution also requires that $\sigma_{\mathrm{Q}}$ exceed 1 .

To obtain an expression for the welfare impact of regulation, we follow steps similar to those in the derivation of $\mathrm{dU} / \lambda \mathrm{L}$ in equation (9). We totally differentiate the utility function as before, and we use the same first order conditions for consumer maximization as before, but we also use the definition of profits. These steps yield:

$$
\frac{\mathrm{dU}}{\lambda \mathrm{L}}=\mathrm{t}_{\mathrm{L}} \hat{\mathrm{L}}-\mu\left(\frac{\mathrm{Y}}{\mathrm{L}}\right) \hat{\mathrm{Y}}+\left(\frac{\mathrm{I}}{\mathrm{L}}\right) \hat{\mathrm{Y}}
$$

The first two terms are identical to those in equation (9) for the effect on the labor distortion and the effect on the externality distortion, but this expression has a third term to account for the extra effect on the monopoly distortion. ${ }^{31}$ The usual partial equilibrium model might compare the last two terms to see if the monopolist raises price toward (or above) the social marginal cost of output. For example, if the initial $\mathrm{p}_{\mathrm{Y}}$ is 1.2 , then profits are $20 \%$ of the cost of production of $\mathrm{Y}$. If this $\mathrm{Y}$ is still $15 \%$ of total output, then $(\Pi / \mathrm{L})$ is 0.03 in the equation above. The policy $\hat{\mathrm{Y}}<0$ has a negative effect on welfare from exacerbating the monopoly distortion. But if $\mu=0.2$, then $\mu(\mathrm{Y} / \mathrm{L})$ is also 0.03 in equation (44), and these two effects exactly offset. The monopolist already raises price to 1.2 , which exactly reflects the social marginal cost of production $(1+\mu)$. However, that partial equilibrium model neglects the effect of $\hat{\mathrm{Y}}$ on $\hat{\mathrm{L}}$ in the first term of (44). We show below that labor supply, and thus welfare, must fall. The implication is that the reverse policy with a forced increase in output would raise welfare (despite the externality).

These results depend entirely on whether the monopolist has left the price of output below the marginal social cost of production or has already raised it above the marginal social cost of production. Therefore, in numerical results below, we use $p_{Y}=1.2$, and set $\mu$ to 0.1 or 0.3 .

To find the general equilibrium effect on labor supply, we again start with the government's balanced-budget adjustment to the tax rate on labor. Any pre-existing tax rate

${ }^{31}$ An important issue is how to specify the counterfactual. Under one scenario, we could take $\mathrm{Y} / \mathrm{L}$ from the previous competitive model, and suppose that $\mathrm{Y}$ were to become monopolized. We would then calculate a new lower $\mathrm{Y} / \mathrm{L}$ for the monopoly case, and a new lower benefit from reduction of pollution $(\mu \mathrm{Y} / \mathrm{L})$. Under a different scenario, $\mathrm{Y} / \mathrm{L}$ is an observed value like 0.15 , and we ask what would happen if that outcome represented a monopolized sector instead of a competitive sector. We take this latter course, since it maintains the size of the polluting sector (and thus $\mu \mathrm{Y} / \mathrm{L}$ ) across the two models. 
on profits is not adjusted. The government budget constraint in equation (11) is unchanged, but now profits exist prior to the imposition of any new policy. Moreover, the change in profits is driven by equation (39). We differentiate equation (11), use the expression for profits in equation (41) as well as the change in profits in equation (39) to obtain:

$$
\hat{\mathrm{t}}_{\mathrm{L}}=-\left(\frac{\mathrm{t}_{\mathrm{L}}}{1-\mathrm{t}_{\mathrm{L}}}\right) \hat{\mathrm{L}}-\left(\frac{\phi \mathrm{t}_{\Pi}}{\epsilon_{\mathrm{Y}} \mathrm{S}_{\mathrm{L}}}\right)\left(\hat{\mathrm{Y}}+\epsilon_{\mathrm{Y}} \hat{\mathrm{p}}_{\mathrm{Y}}\right) .
$$

where $S_{\mathrm{L}}$ is the share of after-tax labor income in total after-tax household income.

Next, labor supply is a function of the real net wage and real nonlabor income. Thus environmental regulations affect labor supply both through the effect of $\hat{t}_{L}$ on $\hat{w}$ (equation 15) and the effect of $\hat{\mathrm{Y}}$ on $\hat{\Pi}$ (equation 39). We differentiate the labor supply function to get:

$$
\hat{\mathrm{L}}=\epsilon \hat{\mathbf{w}}+\eta S_{\Pi}\left(\hat{\Pi}-\hat{\mathrm{p}}_{\mathrm{Q}}\right)
$$

where $S_{\Pi}$ is the share of after-tax profits in after-tax income. We then use (39) and (43) to rewrite this expression as:

$$
\hat{\mathrm{L}}=\epsilon \hat{\mathrm{W}}+\eta S_{\Pi}\left(\hat{\mathrm{Y}}+(1-\phi) \sigma_{\mathrm{Q}} \hat{\mathrm{p}}_{\mathrm{Y}}\right)
$$

The expression in parentheses is the percentage change in real profits. Labor supply is affected by changes in the real after-tax wage through $\epsilon$ (including both substitution and income effects) as well as changes in real profits through $\eta$ (effect of nonlabor income).

Finally, we need an expression for the change in the price of $\mathrm{Y}$ attributable to the environmental policy. We can use the equilibrium relationship between $Y$ and $p_{Y}$ to obtain this expression. Totally differentiate the household budget constraint:

$$
\hat{X}=-\frac{p_{Y} Y}{X}\left(\hat{Y}+\hat{p}_{Y}\right)+\frac{\left(1-t_{L}\right) L}{X}\left(\hat{L}-\hat{t}_{L}\right)+\left(1-t_{\Pi}\right) \frac{\Pi}{X} \hat{\Pi}
$$

Substitute this equation into equation (20), and use equations (39), (43), and (45) to get:

$$
\hat{\mathrm{p}}_{\mathrm{Y}}=-\frac{\hat{\mathrm{Y}}}{\epsilon_{\mathrm{Y}}}+\frac{\mathrm{S}_{\mathrm{L}}}{\left(1-\mathrm{t}_{\mathrm{L}}\right)\left(\epsilon_{\mathrm{Y}} \mathrm{S}_{\mathrm{L}}-\phi \mathrm{t}_{\Pi}\right)} \hat{\mathrm{L}} .
$$


At this point, if we take $\hat{\mathrm{Y}}$ as an exogenous policy parameter, we have four equations that are linear in four unknowns. By successive substitution, or Cramer's Rule, equations (15), (45), (47), and (49) can be solved for $\hat{\mathrm{p}}_{\mathrm{Y}}, \hat{\mathrm{t}}_{\mathrm{L}}, \hat{\mathrm{w}}$, and $\hat{\mathrm{L}}$. The long expression for $\hat{\mathrm{L}}$ is not worth repeating here, but we use it to measure the welfare impact of a required reduction in $\mathrm{Y}$. Thus welfare in (44) can be re-expressed as $-\psi \hat{\mathrm{Y}}$.

For parameter values, we cannot use all the same selections as before. In the competitive model, where $\mathrm{p}_{\mathrm{Y}}=1$, we set $(\mathrm{Y} / \mathrm{L})=0.15$ and $\mathrm{t}=0.40$, so government provision must be $40 \%$ of output and $\mathrm{X}$ must be the remaining $45 \%$ of output. These ratios generate $\phi=0.250$ for the expenditure on $\mathrm{Y}$ as a share of the consumer's budget. In the monopoly model, we first assume that the monopolist has set $\mathrm{p}_{Y}=1.2$, so that profits are $20 \%$ of the output of Y. Second, we choose to match the share of $Y$ in total output (Y/L) across models, to keep the pollution impacts comparable. But then the higher price on $\mathrm{Y}$ in the monopoly model means that consumers must be spending more of their income on $\mathrm{Y}$. We derive $\phi$ as the spending $\mathrm{p}_{\mathrm{Y}} \mathrm{Y}=(1.2)(.15)$ as a fraction of total spending $[(1.2)(.15)+.45]$, so $\phi$ must be 0.286 in the monopoly model. Third, we can no longer assume a unit elasticity of substitution between $X$ and $Y$. Since $\mathrm{p}_{Y}=1$.2, equation (38) says that $\epsilon_{\mathrm{Y}}$ must be 6 , and equation (43) says that $\sigma_{\mathrm{Q}}$ must be 8 . These values may seem high, but our model only has two commodities. The reality that constrains the price charged by a monopolist from being even higher is that some other good can serve as a reasonably close substitute. To be able to compare results, we use this value $\left(\sigma_{Q}=8\right)$ in both the competitive model and in the monopoly model. ${ }^{32}$

Finally, in cases where the pre-existing $t_{\pi}$ is positive, then the initial monopoly profits must be generating some tax revenue. In those cases, we keep government spending at $40 \%$ of national output by reducing the initial tax on labor supply according to:

$$
\mathrm{t}_{\mathrm{L}}=\frac{\mathrm{G}}{\mathrm{NL}}-\mathrm{t}_{\Pi} \frac{\Pi}{\mathrm{L}} .
$$

Table 3 presents results for these parameters when $\mathrm{Y}$ is provided by a monopolist and for purposes of comparison, also in a perfectly competitive market. All rows assume that the labor supply elasticity $\epsilon$ is 0.3 , and the first two rows vary the externality $(\mu=0.1$

${ }^{32}$ When $\sigma_{\mathrm{Q}}$ is fixed across the two models, but $\phi$ is not, equation (43) says that $\epsilon_{\mathrm{Y}}$ must be 6.25 in the competitive model and 6 in the monopoly model. 
Table 3

Welfare Effect of a Small Cut in Pollution:

Monopoly Production of the Polluting Good

\begin{tabular}{|c|c|c|c|c|c|c|c|c|c|}
\hline \multirow{2}{*}{\multicolumn{2}{|c|}{$\begin{array}{l}\text { Assumed } \\
\text { Parameter } \\
\text { Values }\end{array}$}} & \multirow{2}{*}{$\begin{array}{c}\text { Gain from } \\
\text { Externality } \\
\text { Correction } \\
\text { (1) } \\
\end{array}$} & \multicolumn{3}{|c|}{ Perfect Competition } & \multicolumn{4}{|c|}{ Monopoly } \\
\hline & & & $\begin{array}{l}\text { Tax Rate } \\
\text { on Labor }\end{array}$ & $\begin{array}{l}\text { Loss from } \\
\text { Labor } \\
\text { Distortion }\end{array}$ & $\begin{array}{l}\text { Net Effect } \\
\text { on Welfare }\end{array}$ & $\begin{array}{l}\text { Tax Rate } \\
\text { on Labor }\end{array}$ & $\begin{array}{l}\text { Loss from } \\
\text { Monopoly } \\
\text { Distortion }\end{array}$ & $\begin{array}{l}\text { Loss from } \\
\text { Labor } \\
\text { Distortion }\end{array}$ & $\begin{array}{l}\text { Net Effect } \\
\text { on Welfare }\end{array}$ \\
\hline$t_{\Pi}$ & $\mu$ & $\mu(\mathrm{Y} / \mathrm{L})$ & $t_{L}$ & $t_{L} \hat{L}$ & $\psi$ & $t_{L}$ & $\Pi / L$ & $t_{L} \hat{L}$ & $\psi$ \\
\hline 0 & 0.1 & 0.015 & 0.40 & 0.010 & 0.005 & 0.40 & 0.030 & 0.007 & -0.022 \\
\hline 0 & 0.3 & 0.045 & 0.40 & 0.010 & 0.035 & 0.40 & 0.030 & 0.007 & 0.008 \\
\hline$t_{L}$ & 0.3 & 0.045 & 0.40 & 0.006 & 0.039 & 0.388 & 0.030 & 0.007 & 0.008 \\
\hline 1.0 & 0.3 & 0.045 & 0.40 & 0 & 0.045 & 0.37 & 0.030 & 0.006 & 0.009 \\
\hline
\end{tabular}

Government spending is $40 \%$ of total output, the uncompensated labor supply elasticity $\epsilon$ is 0.3 , the labor supply income elasticity $\eta$ is -0.2 , and the elasticity of substitution in consumption $\sigma_{\mathrm{Q}}$ is 8 . The pollution generating good comprises $15 \%$ of total output. Prior to the mandated restriction, the price of $\mathrm{Y}$ is 1 in the competitive model, and 1.2 in the monopoly model. The share $\phi$ is $1 / 4$ in the competitive model and .286 in the monopoly model. $\epsilon_{\mathrm{Y}}$ equals 6.25 in the competitive model and 6 in the monopoly model. 
and 0.3 ). We first analyze results for the perfectly competitive model. Note that the results for this competitive model differ from those in Table 1, primarily by assuming a greater degree of substitutability between $\mathrm{X}$ and $\mathrm{Y}$ in consumption. And because consumers have this greater ability to substitute in consumption, the forced reduction in $\mathrm{Y}$ has less impact on raising the price of $\mathrm{Y}$. The consequence is a smaller decrease in the real net wage and a lower loss from increasing the labor market distortion. To see the impact of increasing $\sigma_{\mathrm{Q}}$ from 1 to 8 , compare the first row of Table 3 to the second row of Table 1 (with the same $\epsilon=0.3$ and $\mu=0.1$. The labor market loss is cut by more than $80 \%$, from 0.062 to 0.010 . Since this loss is so much smaller, and the environmental gain is still 0.015 , this change in $\sigma_{\mathrm{Q}}$ has converted the overall effect on welfare from negative in Table 1 to positive in Table 3 . The next row in Table 3 shows that increasing the marginal environmental damage from 0.1 to 0.3 also increases this net gain.

The remaining rows of Table 3 keep $\mu=0.3$ and show the effect of alternative values for the initial tax on profits. As in Table 1, a higher tax on profits reduces the handout of scarcity rent, which blunts the fall in labor supply attributable to that income effect. With $100 \%$ profits tax, in the last row, all incremental labor market distortions are eliminated. Then the net welfare effect is simply the gain from correcting the externality.

The right half of Table 3 presents results from the monopoly model. First note that the tax rate on wage income is no longer fixed at $40 \%$. With pre-existing profits, a higher initial profits tax implies that a lower initial labor tax is required to raise $40 \%$ of national income. The first two rows present results for the case where profits are untaxed (and the labor $\operatorname{tax}$ is $40 \%$ ). The reduction in labor supply in the monopoly model is $70 \%$ of the reduction in the perfect competition model (as evidenced by the loss from the labor market distortion in columns 3 and 7). Households do not reduce labor supply as much in the monopoly model because the environmental policy reduces monopoly profits, and leisure is a normal good. When $\mu$ is only 0.1 , however, the net welfare effect of the regulation turns from positive in the competitive model to negative in the monopoly model. The reason is that this monopolist has already raised price $\left(\mathrm{p}_{\mathrm{Y}}=1.2\right)$ above social marginal cost $(1+\mu)$. The loss from exacerbating the monopoly distortion combined with the loss from exacerbating the labor distortion then exceed the environmental gain.

When $\mu=0.3$, the monopolist with $\mathrm{p}_{\mathrm{Y}}=1.2$ has not restricted output "enough." In this case the loss from the monopoly distortion $(0.03)$ is less than the environmental gain (0.045). Now the net welfare effect depends on the labor distortion! In the monopoly 
model, however, the loss from the labor distortion is a paltry 0.007 . Why? First, the impact on labor is reduced substantially by the use of $\sigma_{Q}=8$, as mentioned above, in both the competitive model and the monopoly model. When consumers can substitute into other goods, the policy has smaller effect on the price of $\mathrm{Y}$. It therefore has smaller effect on the real net wage and on labor supply. Second, in the monopoly model, the environmental policy reduces pre-existing profits. The loss of income has a positive effect on labor, since leisure is normal, which provides a "partial offset" to the negative effect from the lower real net wage. These factors shrink $\hat{\mathrm{L}}$ to only -0.016 , which is multiplied by $t_{L}=0.4$ to get the loss in welfare $(0.007)$.

The last three rows of Table 3 show that changes in $t_{\Pi 1}$ have virtually no effect on the paltry 0.007 loss from the labor distortion (column 7). ${ }^{33}$ Why? First, a higher initial profits tax means that the income effect (from the change in monopoly profits) is smaller. Thus the "partial offset" just mentioned is smaller, and labor supply does fall a bit more. The real wage falls by about -0.058 in all three rows, and profits fall by about -0.038 in all three rows, but the higher tax on profits makes the income effect smaller. With $100 \%$ profits tax, and no income effect to offset the wage effect, labor supply falls by the full $\epsilon \hat{w}$, which is $(0.3)(-0.058)=-0.017$. Second, even though the higher profits tax enlarges the effect on labor supply (slightly), it reduces the initial required labor tax. The net effect on welfare is the product, $t_{L} \hat{L}$, so these two effects offset each other, and the loss from the labor distortion is essentially unchanged.

The results from this section illustrate a couple of points about environmental policies that restrict output. First, the exacerbation of distortions arising from imperfect competition can be very important and could potentially more than offset any gains from improving the environment, even ignoring effects on labor supply. This point may be particularly important for energy-producing industries, those most likely to fail conditions for perfect competition. Second, these monopoly results affect the previous result in the competitive model where we emphasized that government could prevent the fall in the real net wage if it were to capture all of the scarcity rents by $100 \%$ profits tax, or by sale instead

${ }^{33}$ When the profits tax rate is zero, the $40 \%$ labor tax raises enough to provide spending that is $40 \%$ of total output (L). The penultimate row finds the single tax rate on both profits and labor $(38.8 \%)$ that raises the same revenue for the initial equilibrium. The last row considers a $100 \%$ profits tax, so the same spending is possible with a labor tax of only $37 \%$. (We assume the firm continues to maximize profits despite a $100 \%$ tax rate). 
of handout of permits. This result does not hold in a model with pre-existing profits, because the environmental policy reduces those pre-existing profits. In the case of complete profits taxation, for a $1 \%$ output restriction, profits fall by $-.038 \%$. This change requires government to increase the tax on wages to make up lost tax on profits. The result is that a $1 \%$ output restriction does reduce the real net wage (by $0.058 \%$ ).

\section{Conclusion}

We have considered a number of environmental policies in different general equilibrium models to assess how these policies interact with pre-existing distortions. Whether we analyze tradeable pollution permits, direct controls on emissions, subsidies for non-polluting activities, or mandated technology adoptions, we find a common theme in our results. The magnitude of the welfare gain (or possibly the loss) due to new environmental policies in the face of pre-existing distortions depends critically on 1) whether the policy generates scarcity rents and 2) whether those rents are captured by the government and used to lower other distorting taxes. In our first set of models, where producers are perfectly competitive, environmental policies enhance welfare by reducing pollution but can reduce welfare by discouraging labor supply. The net welfare change depends on the relative size of these two factors. The key in these models to understanding the impact on labor supply is to focus on the real net wage. When a policy generates scarcity rents, it leads to an increase in the price level that reduces the real net wage and hence labor supply. The only way to avoid this adverse effect on efficiency is for government to capture the rents (through a $100 \%$ tax on profits, or the sale of all tradeable permits), or to avoid generating the rents (through mandated technologies for all existing firms and entrants). Thus, much of the focus in our paper is on the sources and disposition of these scarcity rents.

Recognizing the importance of scarcity rents clarifies a source of possible confusion in the "double dividend" literature. Much of the emphasis in this literature has been the role that the revenue from the Pigouvian tax plays in allowing a reduction in other tax rates. Our analysis of different policies shows that this emphasis is misplaced. Following the doubledividend literature's assumption that the budget is balanced by adjusting the labor tax rate, we demonstrate equivalent welfare results whether government were to 1) raise revenue by taxing pollution or selling tradeable permits, 2) lose revenue by subsidizing the clean alternative to the polluting good or input, or 3) collect no revenue by using a technology mandate. Small changes in any of these three directions have no effect on the real net wage or on the labor market distortion. 
We derive these results analytically in a number of models. We first consider the case where pollution is directly associated with a final commodity, and we then extend the model to the case where pollution is associated with an input to production. This latter case allows for the possibility that substitution in production can mitigate welfare losses. We consider the interaction among three distortions: imperfect competition, pre-existing taxes, and pollution. To our knowledge, our effort is the first to examine these three distortions simultaneously in a general equilibrium model. The ability to consider a wide variety of policies in a number of different models illustrates the power of the comparative statics approach that we employ in this paper. 


\section{References}

Atkinson, Scott E., and Donald H. Lewis, "A Cost-Effectiveness Analysis of Alternative Air Quality Control Strategies," Journal of Environmental Economics and Management, 1: 1974 , pp. $237-50$.

Ballard, Charles L. and Steven G. Medema, "The Marginal Efficiency Effects of Taxes and Subsidies in the Presence of Externalities: A Computational General Equilibrium Approach," Journal of Public Economics, 52: 1993, pp.199-216.

Barnett, Andy H., "The Pigouvian Tax Rule Under Monopoly," American Economic Review, 70: 1980, pp. 1037-41.

Berndt, Ernst R., and David O. Wood, "Technology, Prices, and the Derived Demand for Energy," Review of Economics and Statistics, 57: 1975, pp. 259-68.

Bohm, Peter, and Clifford F. Russell, "Comparative Analysis of Alternative Policy Instruments," in Kneese, Allen V. and James L. Sweeney, eds., Handbook of Natural Resource and Energy Economics, Volume 1, New York: Elsevier, 1985, pp. 395-460.

Bovenberg, A. Lans, and Lawrence H. Goulder, "Optimal Environmental Taxation in the Presence of Other Taxes: General Equilibrium Analyses," American Economic Review, 86: 1996, pp. 985-1000.

Bovenberg, A. Lans, and Ruud. A. de Mooij, "Environmental Levies and Distortionary Taxation," American Economic Review, 94: 1994, pp. 1085-89.

Browning, Edgar K., "On the Marginal Welfare Cost of Taxation," American Economic Review, 77: 1987, pp. 11-23.

Browning, Edgar K., "The Non-Tax Wedge," Journal of Public Economics, 53: 1994, pp.419-33.

Buchanan, James M., and Gordon Tullock, "Polluters' Profits and Political Response: Direct Controls Versus Taxes," American Economic Review, 65: 1975, pp. 139-47.

Caddy, Vern, "Empirical Estimation of the Elasticity of Substitution: A Review," Working Paper OP-09, IMPACT Project, Industrial Assistance Commission, Melbourne, Australia: 1976.

Cropper, Maureen L., and Wallace E. Oates, "Environmental Economics: A Survey," Journal of Economic Literature, 30: 1992, pp. 675-740.

Feldstein, Martin, "The Effect of Marginal Tax Rates on Taxable Income: A Panel Study of the 1986 Tax Reform Act," Journal of Political Economy, 103:1995, pp. 551-72.

Freeman, A. Myrick, Air and Water Pollution Control: A Benefit-Cost Assessment, New York: John Wiley and Sons: 1982. 
Fuchs, Victor, Alan Krueger, and James Poterba, "Empirical Research, Values, and Economic Policy," work in progress, Stanford University, 1997.

Fullerton, Don and Ann Wolverton, "The Case for a Two-Part Instrument: Presumptive Tax and Environmental Subsidy," NBER WP\#5993, Cambridge, MA, 1997.

Goulder, Lawrence H., "Environmental Taxation and the 'Double Dividend': A Reader's Guide," International Tax and Public Finance, 2: 1995, pp.157-183.

Goulder, Lawrence H., Ian W. H. Parry, and Dallas Burtraw, "Revenue-Raising vs. Other Approaches to Environmental Protection: The Critical Significance of Pre-Existing Tax Distortions," NBER WP\# 5641, Cambridge, MA, 1996.

Hamermesh, Daniel, Labor Demand, Princeton NJ: Princeton University Press, 1993.

Harris, Richard, "Applied General Equilibrium Analysis of Small Open Economies with Scale Economies and Imperfect Competition," American Economic Review, 74:1984, pp. 1016-32.

Kaplow, Louis, "The Optimal Supply of Public Goods and the Distortionary Cost of Taxation," National Tax Journal, 49: 1996, pp. 513-33.

Lee, Dwight R. and Walter S. Misiolek, "Substituting Pollution Taxation for General Taxation: Some Implications for Efficiency in Pollution Taxation," Journal of Environmental Economics and Management, 13: 1986, pp. 338-47.

Maloney, Michael T., and Robert E. McCormick, "A Positive Theory of Environmental Quality Regulation," Journal of Law and Economics, 25: 1982, pp. 99-123.

Oates, Wallace E., "Green Taxes: Can We Protect the Environment and Improve the Tax System at the Same Time?" Southern Economic Journal 61: 1995, pp. 914-22.

Parry, Ian W. H., "Environmental Taxes and Quotas in the Presence of Distorting Taxes in Factor Markets," Resource and Energy Economics, forthcoming, 1997a.

Parry, Ian W. H., "A Second-Best Analysis of Environmental Subsidies," International Tax and Public Finance, forthcoming, $1997 \mathrm{~b}$.

Pearce, David, "The Role of Carbon Taxes in Adjusting to Global Warming," The Economic Journal, 101: 1991, pp. 938-48.

Pearce, David W., and R. Kerry Turner, Economics of Natural Resources and the Environment, Baltimore: Johns Hopkins Press, 1990.

Repetto, Robert, Roger C. Dower, Robin Jenkins, and Jacqueline Geoghegan, Green Fees: How a Tax Shift Can Work for the Environment and the Economy, Washington DC: World Resources Institute, 1992.

Rosen, Harvey, "What is Labor Supply and Do Taxes Affect It?," American Economic 
Review, 70: 1980, pp. 171-6.

Russek, Frank S., "Labor Supply and Taxes," CBO Memorandum, Washington DC: U.S. Congressional Budget Office, 1996.

Russell, Clifford, "Monitoring and Enforcement," in Portney, Paul R., ed., Public Policies for Environmental Protection, Washington, DC: Resources for the Future, distributed by Johns Hopkins University Press, Baltimore, 1990, pp. 243-74.

Seskin, Eugene P., Robert J. Anderson, and Robert O. Reid, "An Empirical Analysis of Economic Strategies for Controlling Air Pollution," Journal of Environmental Economics and Management, 10:1983, pp. 112-24.

Stavins, Robert N., "Transaction Costs and Tradeable Permits," Lournal of Environmental Economics and Management, 29: 1995, pp. 133-48.

Stuart, Charles, "Welfare Costs per Dollar of Additional Tax Revenue in the United States," American Economic Review, 74: 1984, pp. 352-62.

Terkla, David, "The Efficiency Value of Effluent Tax Revenues," Journal of Environmental Economics and Management, 11: 1984, pp. 107-23.

U.S. Bureau of the Census, Statistical Abstract of the United States: 1995, Washington, DC: US Government Printing Office, 1995.

Weitzman, Martin L., "Prices vs. Quantities," Review of Economic Studies, 41:1974, pp. 477-91.

Wicke, Lutz, "Environmental Damage Balance Sheets," in N. Akerman, ed., Maintaining a Satisfactory Environment: An Agenda for International Environmental Policy, Boulder: Westview Press, 1990. 